\title{
The early modern transmission of the ancient Greek romances: a bibliographic survey
}

\author{
KIRSTEN RICQUIER \\ Ghent University
}

This contribution offers a new, critical bibliography of the early modern translations and editions of the five extant Greek romances. ${ }^{1}$ The early modern era was a crucial period for their afterlife: it was the age of print, enabling their wider dissemination across Europe, and the large number of prints of the Greek romances in the classical languages or vernacular echoed and contributed to their popularity as models for imitations and adaptations. So far, there have not been many attempts to create a bibliography of these works, and the existing ones are only partial. In some cases, they are mentioned in more general bibliographies of translations of classical texts. ${ }^{2}$ When more specific, the bibliographies usually only concern one romance. ${ }^{3}$ Two scholars attempted to compose a bibliography for several Greek novelists: Gesner (1970:145-162) and Plazenet (1997:685-702) provide a long list for Heliodorus, Achilles Tatius, and Longus, in France and Britain during the sixteenth and seventeenth centuries. ${ }^{4}$ These bibliographies have, however, their limitations as reference tools for the early modern epoch.

${ }^{1}$ This article is based on an MA dissertation written at Ghent University in 2016-2017 under the supervision of Professor Koen De Temmerman, to whom I am very grateful for all his advice. It is written under the European Union's Seventh Framework Programme (FP/2007-2013) with the support of the European Research Council Starting Grant Novel Saints (Grant Agreement n. 337344) at Ghent University.

${ }^{2}$ See Degen 1798, Hoffmann 1839, Pettegree, Walsby and Wilkinson 2007.

${ }^{3}$ Oeftering (1901), Mazal (1966), and Colonna (2015:27-29) for Heliodorus, MacQueen (1990:261-267), Barber (1989) and Ferrini (1991) for Longus, or Nakatani (2005:253-256) for Achilles Tatius.

${ }^{4}$ A very short, chronological overview has also been provided by Létoublon (2015:75-77). A short, older bibliography was produced for all Greek romances and related texts by a certain C. d'I*** (Anonymous 1864:334-340). 
Plazenet, according to her subject, focuses only on the sixteenth and seventeenth centuries. Gesner starts earlier, from the beginning of print, but also ends earlier, in 1642. Furthermore, a lot of her entries are dubious, and her bibliography neglects the Polish and Hungarian translations. Indeed, these have often gone unnoticed, or are only mentioned with incomplete information, as in the case of Oeftering (1901:51). Gesner is not the only scholar whose bibliography is faulty or incomplete: those by Oeftering, MacQueen, and Colonna contain many gaps, and often seem to copy the mistakes of others. Finally, a reason why it is really necessary to undertake a new bibliographic survey, is that the surveys are old and not up to date. In recent decades, new discoveries have provided new information about the transmission. Some translations have been newly discovered, such as the fact that Cozad (2013) argues against the common assumption that Longus was not known in Spain until the late Spanish translation by D. Juan Valera in 1880 , because she notices that some lines of the romance had already been freely translated/adapted by Damasio de Frías y Balboa in 1568. Others have been cast into doubt. For example, there may have been a reprint of Manzini's Italian translation of Longus in Bologna in 1647, but Ferrini rightly says: "molto dubbia la reale esistenza di questa ed. segnalata da molti autori che dichiarano di non averla vista" (Ferrini 1991:95). Furthermore, some attributions have been corrected since earlier bibliographies. Les devis amoureux, for example, a French translation of Achilles Tatius, was often attributed to Claude Collet in older bibliographies. ${ }^{5}$ According to the Bibliothèque Nationale de France, Nakatani (2005:910), and Pettegree (2007:4), however, Philibert de Vienne is its true author.

My bibliography differs from earlier bibliographies because it intends to be broader, more critical, and up to date. First of all, it is based on new findings. It is the first systematic attempt to compile a specific bibliography of the Greek romances twenty-one years after Plazenet. Secondly, it is broader, because I do not limit myself to only one Greek romance but to the extant, so-called "Big Five", and I have included their translations in all the European languages in which they became available in early modern history. Thirdly, it also includes translations which were completed but not published. For those reasons, my bibliography contains new entries not included in existing bibliographies, such as the unpublished Hungarian translation of Heliodorus by Mihály Czobor. Fourthly, it covers the entire early modern era (unlike Plazenet, Gesner, and Létoublon (2015:75-77)). Although the eighteenth century was relatively neglected by scholarship concern-

\footnotetext{
${ }^{5}$ See e.g. Reynier, G. (1969). Le roman sentimental avant l'Astrée. Genève: Slatkine, p. 159.; Gesner 1970:154.
} 
ing the ancient romances, it was an important era: in this century, the Greek romances served their last days as popular models for adaptations, ${ }^{6}$ as gradually the so-called "rise of the novel" and the growing negative attitude towards "romances" pushed them aside. Furthermore, as is well known, Xenophon and Chariton were rediscovered in this century after a long period of silence. In short, the eighteenth century was a turning point in the afterlife of the Greek romances, as attitudes towards them shifted from their early modern popularity and enormous influence to a new, modern approach. Therefore, my survey covers the period from their re-emergence in the fifteenth century to the eighteenth century. Finally, I correct the existing lists with findings from my own investigations into catalogues, consultations of digital copies, and secondary literature.

By way of explanation, on the following pages I will provide information about some bibliographic particularities necessary for a correct understanding of my survey, as well as a justification of choices I made about alleged editions, translations that deal freely with the original texts, and editions and translations that do not contain the complete romance. I will also discuss the history of their transmission (rediscovery, changing interests, tendencies ...), their geographical dissemination across Europe, the popularity of some of those in print and as models for other versions, and combinations with other texts. ${ }^{7}$

\section{To have been or not to have been? Alleged editions}

For some of the prints mentioned in earlier bibliographies, there exists uncertainty as to whether they actually ever existed. Gambara's Expositi, a Latin translation of Longus, is such an example. Vieillefond (1987:1xiii) mentions an alleged edition in Basel in 1555, MacQueen (1990:264) and Gesner (1970:161) refer to one in Rome in 1569 titled Expositorum ex Longo libri iv heroico carmine, and several

${ }^{6}$ See among others Adams, P.G. (2015). Travel Literature and the Evolution of the Novel. Kentucky: University of Kentucky Press, pp. 237-238; Sandy 1976 and 1982:108-110; Pattoni, M.P. (2014). Longus' Daphnis and Chloe: literary transmission and reception. In: E.P. Cueva and S.N. Byrne, eds., A companion to the ancient novel. Chichester: WileyBlackwell, p. 589.

${ }^{7}$ These are the bigger tendencies which can be discerned. But some smaller details are interesting as well, e.g. the fact that the Greek novelists are not always acknowledged in the title (see Classe (2000 Vol.I: 864-5) for some English translations of Longus, and Seeber (2017) for Zschorn's intentional obliteration of Heliodorus) or receive an epithet (Achilles Tatius is frequently called "the Alexandrian" and Longus "the sophist"). One can also distinguish differences among the Greek novelists, both in their popularity in print as well as the appearance of their editiones principes and first translations, but this has already been noted by other scholars such as Hofmann (2001:107). 
scholars such as Asor Rosa (1999:53) ${ }^{8}$ and Ferrini (1991:89) mention a Plantine edition printed in Antwerp in 1569. Hofmann, who conducted a thorough investigation into catalogues and libraries, did not find these alleged editions, and refers to them as "phantom editions that haunt the bibliographies where generations of scholars have copied these wrong entries from each other, and should be removed for good from the bibliographies of Longus." (Hofmann, 2011:110). I agree with Hofmann and consider the 1574 Naples edition as the true first print of Gambara's translation, the existence of which can be verified thanks to a digitalised copy. For reasons of completeness and correctness, I distinguish between the indubitable and dubious (re)prints by displaying the latter - with a reference to secondary literature claiming their existence - separately a line below the (re)prints whose existence is certain.

Regarding some translations, we do not know if they ever existed at all. For example, all bibliographies of Longus that include German translations contain a reference to David Wolstand (often as "Anonymous"), but I found no evidence of any existing work by this author. Already in 1785, the German journal Für aeltere Litteratur und neuere Lectüre expresses doubt about its existence: "Ob sie wirklich erschienen, weiss ich nicht; denn der damalige Messkatalogus, hat so wie der iezige, öfters Bücher angekündigt, oder als fertige angezeigt, die niemalen das Licht erblikt haben." (s.n. 1785:31). ${ }^{9}$ Maybe those dubious translations are simply lost, but we cannot be sure. For completeness, I include them in the survey, but unlike other bibliographies, I distinguish them from the other lemmata by placing them between two daggers $(\dagger \ldots \dagger)$ to indicate their uncertain status.

\section{In the twilight zone between translation and adaptation}

The definition of the term "translation" is vague and can be interpreted in various ways, according to individual preferences of scholars and translators. Some of my entries are considered as translations by some, and as paraphrases or even adaptations by others, because they are not word by word translations. Thus, Oeftering (1901:51) argues that the Dutch translation of Heliodorus by Gentil is actually a retelling of the story. And the Spanish version of Achilles Tatius by Diego Agreda y Vargas is, in Nakatani's opinion (2005:18), a free adaptation. As I intend to give a broad survey, I take the meaning of "translation" not too strictly, and I also take

\footnotetext{
${ }^{8}$ Asor Rosa, A. (1999). Gambara, Lorenzo. Dizionario Biografico degli Italiani, 52, pp. 5354.

${ }^{9}$ S.n. (1785). Für aeltere Litteratur und neuere Lectüre, Dritter Jahrgang, Vierter Heft. Leipzig: J.G.I. Breitkopf.
} 
into account more creative interpretations of that concept and the more original variations by which the Greek romances so often reached the audience. ${ }^{10}$ Furthermore, I also include translations that $d o$ translate word by word but not in a very strict sense, such as translations in which some passages are translated word by word and others are summarised or adapted, and other translations in which an extra twist has been added, like inserting episodes of their own invention, rearranging the story, as in the case of Malnoury's French Heliodorus, ${ }^{11}$ or putting the translated sentences into verse. Indeed, a recurring tendency is not only to translate the words into another language, but also to convert prose into poetry. Czobor and Gyöngyösi both provide a translation of Heliodorus into Hungarian verses. ${ }^{12}$ Similarly, William Lisle converts the Aethiopica into English metres, and Bossi the first five books into Italian "ottavo rima". Also Longus has been converted into verse: Gambara versifies the sentences in Latin dactylic hexameters, a choice of metre which situates the romance in the epic tradition. For this transposition of a prose work into poetry, MacQueen (1990:264) prefers to call it a paraphrase, and Reeve (2008:289) even refers to a free adaptation. Also, the French translation of Longus by Pierre Marcassus is commonly considered a paraphrase. Longus, in particular, seems to have attracted peculiar treatments like this. ${ }^{13}$

${ }^{10}$ Sometimes the authors themselves announce in their title or preface the freedom they take with the original, like Sanford's "the Hystorie of Cariclea \& Theagenes (gathered for the most part out of Heliodorus)" or Lisle's "The famous historie of Heliodorus. Amplified, augmented, and delivered paraphrastically in verse" (my emphasis).

${ }^{11}$ Nakatani (2005:135) argues that Malnoury de la Bastille rearranged the Aethiopica into chronological order, because an in medias res structure was no longer admired.

${ }^{12}$ Regarding the translations of Heliodorus by the Hungarians György, Czobor, Gyöngyösi, and Dugonics, see Rajka (1917). For Czobor and Gyöngÿosi also Zsák, I.A. (1901). Czobor Mihály a Chariclia első magyar forditója. Irodalomtörténeti Közlemények, 11(1), pp. 5362. For a more recent reference, including the Hungarian Achilles Tatius, see Kiss (2017:266). See also the following website for Czobor: Jankovics, J., Köszeghy P., and Szentmártoni, S.G. (s.d.). Régi magyar irodalmi szöveggyüjtemény II. 7. fejezet - VERSES REGÉNY. Czobor Mihály(?): Theagenes és Chariclia: http://www.tankonyvtar.hu/hu/ tartalom/tkt/regi-magyar-irodalmi-2/ch07.html [Accessed 22 March 2018].

13 According to Gillespie and Hopkins (2005:302), James Craggs's English version of Longus is at times a summary, at times a translation. Next, Cozad (2013) argues that the Spanish humanist Damasio de Frías y Balboa provides a partial translation/adaptation of Daphnis and Chloe in his chivalric romance Lidamarte de Armenia (1568) as an interpolated episode. Angell Daye frequently paraphrases Amyot's French translation in English, instead of translating it directly, but the liberty he takes with the romance goes further than that: in the third book he introduces a virgin queen reigning over the island of Lesbos, like the British Monarch, as well as shepherds celebrating a holiday in Her honour, after which he inserts a lengthy pastoral poem titled "The Shepheards Holidaie". Something similar happens to Achilles Tatius, among others, in the French translation by A. Rémy, pseudonym for Abraham Ravaud: Nakatani (2005:17) notices that several parts are rewritings or 


\section{Incompleteness: excerpts, lacunae, omissions}

Not all items in my list contain the entire romance, as is sometimes indicated by their titles ("fragmentum", "liber primus", etc.). In some cases, translators/editors consciously select just part of the story to translate. The Italian humanist Angelo Poliziano is the first person in the early modern era to quote a passage from Xenophon's Ephesian Tale. When he discusses the temple in Ephese in chapter 51 of his Miscellanea Centuria Prima, he translates the scene depicting the procession to the temple of Artemis (1.2.2-5) into Latin. ${ }^{14}$ Heliodorus, for his part, gets several versions of the first book (Renatus Guillonius, Wechel, Abraham Fraunce, Lancelot de Carle ${ }^{15}$ ). This says something about the importance of the first book: as Sandy (1979) explains, the abrupt opening in medias res prompts readers to try, like the brigands, to make sense of the strange, bloody scene of the opening sequence, and as the riddle of the identity of the protagonists gradually unravels, the first book establishes itself as an admirable piece of literary cunning, considered a model for imitation and emulation.

In other cases, the fragmentary state can be explained by the fact that the edition/translation is based on an incomplete manuscript or other editions with lacunae. The editorial history of Achilles Tatius' Leucippe and Clitophon provides an interesting example. Annibale della Croce, also known as Cruceius, provides the first Latin translation in 1544, and indicates the condition of the text by using the word "fragmentum" in his title: it is based on an incomplete manuscript which only contains the last four books, the Sinaiticus gr. $1197 .{ }^{16}$ The Italian translation by Dolce and the French one by Philibert de Vienne are also based on this incomplete Latin version. Ten years later, Achilles Tatius receives his first full Latin translation. Philip Archinto informs della Croce that a full manuscript of Achilles Tatius exists in Rome - perhaps, as Nakatani (2005:11) suggests, the Vaticanus Graecus 114. Della Croce adds to his earlier translation the first four books and some corrections to the last four. ${ }^{17}$ Meanwhile, another Italian, Francisco Coccio, had translated the entire text, this time in the Italian vernacular, and with acknowledgement to Achilles Tatius, from another complete manuscript in Venice which Nakatani (2005:11) identifies as the Marcianus Graecus 409. Half a century later,

invented episodes, between the word by word translated parts. For more information about the free paraphrases/translations of Longus, see Classe (2000 Vol.I:865).

${ }^{14}$ Poliziano also mentions the sandals of Philetas in Longus' pastoral romance and the giraffe of the Aethiopica in Caput 2 and 3. For Poliziano's relationship with the Greek romances, see Bianchi (2011:67-98).

${ }^{15}$ Plazenet 2002:250.

${ }^{16}$ Beta 2015:140; Nakatani 2005:9.

${ }^{17}$ Beta 2015:143. 
in 1601, the editio princeps of Achilles Tatius is published, but the Greek text is not complete. Juda and Nikolaus Bonnenvict (alias Bonnvitius) finish the edition started by Commelinus. The text runs from $1,1,1$ to $8,16,3$, then there is a lacuna, and then the text picks up again from $8,17,4 .{ }^{18}$ For a complete edition without lacuna, Achilles Tatius has to wait until 1640, when Claude de Saumaise, also known as Salmasius, produces a new bilingual edition, founded on a comparison of different manuscripts. ${ }^{19}$

Longus, for his part, does not get a single complete version of his romance until the nineteenth century. All early modern translations and editions of Longus contain a gap from 1,13,2 to $1,17,4$, from the scene where Daphnis takes a bath and thereby incites Chloe's love and sexuality to the passage where she gives him her first kiss. Indeed, a complete version of the story does not appear until the modern era, when in 1810 Paul-Louis Courier collates the manuscript of the Florentinus Laurentianus Conv. Soppr. 627, which contains the missing part. Different solutions are invented for this lacuna. Amyot signals the lacuna in book I and leaves it open, so that the text actually makes a strange transition from the moment Daphnis enters the cave to wash himself, to his reaction to Chloe's kiss, but Annibale Caro fills the gap with his own fantasy. ${ }^{20}$ The incompleteness of the romance is sometimes overlooked. For example, Doody (1996:46) claims that in John Cleland's pornographic novel Fanny Hill (1748), the erotic scene of a bathing youth triggering the sexual awakening of the young virgin Harriet recalls Daphnis' bathing scene inciting Chloe's sexual desire and love in Longus' romance. But since this passage is part of the lacuna, it raises the question of whether and, if so, how Cleland could have known about it.

Sometimes the editors and translators intentionally wipe out even more parts in the target text, because the editors and translators have a problem either with the style or the content, especially concerning Achilles Tatius and Longus. As is well known, they are often censured for moral or stylistic reasons. The scene in Longus, where Lycaenion sexually initiates Daphnis, is a case in point. Most

${ }^{18}$ According to Nakatani (2005:14-15), their edition is probably derived from the manuscript Vaticanus Graecus 2367 or Parisinus Graecus 2913. In the opinion of Plepelits (1996:393), it comes from the Palatinus Graecus 52, then in the Palatine Library at Heidelberg, but according to Pouderon (2015:7), however, it is derived from the codex Vaticanus Palatinus graec. 523. See Pouderon, B. (2015). Avant-propos. In: B. Pouderon, ed., Les romans grecs et latins et leurs réécritures modernes: études sur la réception de l'ancien roman du Moyen Age à la fin du XIXe siècle. Actes du colloque de Tours octobre 2013. Paris: Beauchesne Editions, pp. 7-18.

${ }^{19}$ Gesner 1970:149, Nakatani 2005:15.

${ }^{20}$ Viellefond 2016:280. 
translators suppress it, except for Caro ${ }^{21}$ and James Craggs. ${ }^{22}$ Beta (2015:145) remarks that Coccio, Ravaud, and many other translators of Achilles Tatius' romance, even up to the twentieth century, leave Menelaus's apology for the kissing between men untranslated because of the homosexuality, but Belleforest and, according to Jouanno (2015:170), Baudouin, are exceptions. Furthermore, when Longus' simplicity is increasingly appreciated during the eighteenth century, the digressive nature and rhetorical abundance of Leucippe and Clitophon are considered too superfluous, and to be avoided. According to Jouanno (2015:172), d'Égly, for example, rids the romance of digressions, lamentations and ekphraseis for that reason. I include, of course, all versions read by the early modern audience - whether selective, accidentally fragmentary, purposely mutilated and censured, altered, or complete - in the bibliography, which, as the example of Cleland shows, the user should keep in mind.

\section{The history of the transmission}

So far, I have provided an explanation of my survey, but interesting information about the transmission can also be derived from the bibliography itself. Clear tendencies can be identified in the transmission of the romances. ${ }^{23}$ Its history has already been outlined extensively in academic study on the Renaissance and Baroque eras: the re-emergence of the Greek romances in early modern Europe starts with humanists consulting the manuscripts in the fifteenth and sixteenth centuries, and with the publication by Bavarian humanist Vinzenz Heidecker of Heliodorus in 1534 in Basel, under his pseudonym Vincent Obsopoeus, the first print of a Greek romance. The celebrated French translation of Heliodorus by Jacques Amyot, published anonymously in 1547 in Paris, turns the wheel of fortune for the Greek romances: its great success gives rise to the popularity of the Greek romances, Heliodorus in particular, during the sixteenth and early seventeenth centuries, as shown by both the number of editions/translations and the number of adaptations. In the second half of the seventeenth century, the number of new editions and translations diminishes significantly, as well as the number of reprints of earlier ones. Only four new editions and translations appear, limited ge-

\footnotetext{
${ }^{21}$ Berger 1988:147.

${ }^{22}$ Gillespie and Hopkins 2005:302; Classe 2000:864.

${ }^{23}$ For this purpose, other bibliographies such as Gesner (1970), Ferrini (1991), and Plazenet (1997) provide a chronology of the items based on the dates of (re)print. In my opinion, however, it is useful to order them chronologically per author and per language, instead of per year.
} 
ographically to England and the Netherlands: Van Nispen translates Achilles Tatius into Dutch in 1652, Longus receives an English translation by Thornley in 1657 and a bilingual edition by Petrus Moll in the Dutch city Franeker in 1660, and Heliodorus is newly translated into English in 1686, the first five books by an anonymous "person of quality" and the last one by Nahum Tate. ${ }^{24}$ If the alleged anonymous German translation of Achilles Tatius ever really existed, Germany could be added to the map. This downfall in their transmission raises the question of why they seemingly lost their attraction, if the Greek romances thereby also lost their influence as models for imitation and emulation, and why those countries continued printing them.

In the eighteenth century, the Greek romances make a spectacular comeback on the book markets. Although the eighteenth-century development of novel writing causes negative attitudes towards older forms of prose fiction, this does not have a negative impact on their printing. In fact, the production is now at its highest, both in the number of new items and the number of reprints of older versions. Most interestingly, however, are the new interests and tendencies, which make the eighteenth century a clear turning point in the transmission of the Greek romances. Firstly, Europeans are no longer only interested in the sophistic romances, but also take notice of Xenophon and Chariton. Bernard de Montfaucon rediscovers Xenophon in its only surviving codex, the Florentinus Laurentianus Conv. Soppr. 627. It is first copied and translated into Italian by Salvini (1723), before the editio princeps of Cocchi (1726). Chariton is the last Greek novelist to reach early modern readers. The editio princeps only appears in 1750 by Jacques Philippe d'Orville, together with a Latin translation by Reiske. An English translation in 1764 is remarkable, due to another novelty, which is that it is translated by two women as an exercise given to them by their father. Secondly, Longus' fame increases rapidly and eclipses all other Greek romances, not only in printed form but also in their afterlife in art and music. Heliodorus is no longer the king of Greek novel writing: his baroque complexity has to yield for Longus' charming simplicity. It is striking that Daphnis and Chloe gets seventeen new translations and editions, that Caro's Tuscan translation is finally printed almost 250 years after it was made, and that Amyot's Amours Pastorales becomes the most reprinted translation. A final new trend is the grouping of Greek romances into collections. ${ }^{25}$ From the second half of the eighteenth century onwards, it becomes a custom to print them together. Manzini's Italian Longus is printed together with Salvini's Italian Xenophon in 1792. The German professor Mitscherlich compiles

\footnotetext{
${ }^{24}$ According to Gillespie \& Hopkins (2005:302), the person who had initiated it died during the process, and Nahum Tate completed the task.

25 cf. Nakatani 2005:23.
} 
a collection, titled Scriptores Erotici Graeci, of editions of the Greek texts together with a Latin translation, with the exception of Chariton. In Paris, there are two series that reprint translations of Greek romances together, namely the Bibliothèque universelle des dames (1785-6) and the Bibliothèque des Romans grecs traduits en français (1797). In the Bibliothèque universelle des romans (Paris, 1775 and 1782), analyses, quotations and summaries appear of earlier translations into French, by Amyot of Longus (August 1775; reissued 1782, Tome I), by du Perron de Castera of Achilles Tatius (November 1775; reissued 1782, Tome II), by de Fontenu of Heliodorus (April 1776), and by Jourdan of Xenophon (May 1776). A similar treatment (introduction, paraphrase with excerpts) can be found for Longus (Vol. I) and Achilles Tatius (vol. II) in the Traduction des meilleurs romans Grecs, Latins et Gaulois, extraits de la bibliothèque universelle des Romans (Paris, 1785).

\section{The geographical dissemination}

The first prints are confined to Switzerland, France and Italy. In Switzerland and Italy, humanists get hold of the manuscripts, and French Hellenists quickly take an interest in the romances. In the second half of the sixteenth century, they spread further to their neighbours in Germany, cross the Channel to Tudor England, and gain ground in Spain and its dominion in what is now Belgium (with prints in Antwerp). In the first part of the seventeenth century, they also reach the Netherlands during the Golden Age, and eastern Europe. Heliodorus' fame in particular now reaches as far as the Polish-Lithuanian Commonwealth and Hungary: Zacharzewski's Polish translation is published far north in Vilnius, and the Hungarians György and Czobor translate him into Latin and Hungarian, respectively. Achilles Tatius reaches Slovakia, then part of Hungary. The translation by Festus (1620 in the Slovak city Košice, or Kassa in Hungarian) into Hungarian is actually the first appearance of the Greek romances on the Hungarian book markets, as György's and Czobor's Heliodorus do not make it to print. In the second part of the seventeenth century, however, France, Italy and Spain seem to have been satisfied with their popularity in the previous decades, and new items are sourced in the Netherlands and England. But when they are printed again in the eighteenth century, their dissemination continues to the North, West and East. Heliodorus now arrives in Copenhagen with the first Danish translation. The Aethiopica was already known in Hungary (see above), but now two Hungarian translations are finally published: a verse translation by Gyöngyösi is printed for the first time in the 
Slovak city Levoča (in Hungarian: Löcse) and another one by Dugonics in Bratislava (in Hungarian: Poszony). The one by Gyöngyösi is reissued in Hungarian Buda in 1733 and 1763. The Kingdom of Hungary, which includes Slovakia, is now a crown land of the Habsburg Monarchy, but in the second part of the century, Greek romances also reach the Habsburg capital in Austria: not Heliodorus, as is usually the case, but a Greek edition of Longus by Vendotes, and another one of Xenophon in Greek and Latin by von Locella, according to the new tendencies of the era. ${ }^{26}$ In the West, Greek romance expands to Ireland and Scotland: Craggs's translation of Longus is reissued in Dublin in 1763, under a different title from the English prints, and Nahum Tate's Heliodorus is reprinted in Glasgow in 1753. Another geographical shift in the eighteenth century is that, while France had been the most eager to translate and edit the Greek romances, now the Germans are equally interested in them. Furthermore, while new translations appear in Italy in the second part of the eighteenth century after a century of silence, the first translations and editions by Italians are actually published outside of Italy: Salvini and Cocchi print Xenophon in the capital of Great Britain while they are members of the Italian circle in London, and Boccardi makes an Italian version of Xenophon in Cologne in 1730.

A reason why it is interesting to map this dissemination is because a work's first appearance in a country in print often puts its afterlife in the literature and art of that region in motion. It is well known that the successful transmission of the sophistic romances into France, Great Britain and Spain in the sixteenth and seventeenth centuries triggered their function as models for French heroic romances, English Elizabethan romances, and Spanish novelas bizantinas for prose fiction, respectively, as well as for the stage. ${ }^{27}$ Few studies, however, have been undertaken to examine whether their transmission had any impact in the Netherlands, Denmark, Austria and the rest of Eastern Europe, or whether there are regional differences in the treatment of the texts by the translators or imitators. Of course, there does not always exist a causal relationship between the appearance of the texts and their afterlife in art and literature within the same region: the Aethiopica

${ }^{26}$ If one looks at paintings of the Greek romances in the eighteenth century, for example, Heliodorus is no longer depicted but Xenophon and Longus are. See Ricquier, K. (2017). De receptie van de antieke romans bij Fielding en Richardson: de erfenis van een antiek genre in enkele 18e-eeuwse zedenromans. Masters dissertation, Ghent University, Ghent, pp. 111-112. Available at: https://lib.ugent.be/fulltxt/RUG01/002/375/949/RUG01-002375949 20170001 AC.pdf.

${ }_{27}$ See Gesner (1970) for the influence on Shakespeare, and Sandy $(1979,1982)$ for a more general account of the English afterlife of the Greek romances. See de Armas Wilson (2014:3-23), Gual (2011:192), and Rose (1971:94-134) for la novela bizantinas. See Plazenet (1997) for a good overview of their afterlife in France and Great Britain. 
was already known in Denmark with the paintings of Gerrit van Honthorst for the Danish crown prince Christian in $1635,{ }^{28}$ a century before the text was printed in Copenhagen.

\section{Popularity in print and as source texts}

The number of reprints tells us something about popularity. In the sixteenth century, Amyot, Warschewiczki, Underdowne, Zschorn, and della Croce are frequently reissued. In the seventeenth century, Ghini, de Mena, and Coccio also receive several reprints, as do, in the eighteenth century, Schmidius and de Mena (of Heliodorus), Saumaise (of Achilles Tatius), and the - by then old - version by Amyot of Longus, with the new one by James Craggs being popular too. Some are frequently reprinted in combination with other translations or editions. This often occurs in the case of bilingual editions, in which the editor combines the Greek text with a reprint of an older Latin translation, or even the reprint of an old Greek text with one in Latin. Thus, in 1596, Hieronymus Commelinus puts the older Latin translation of Warschewiczki next to his new Greek edition of Heliodorus. In the next century, Bourdelotius, Pareus and Schmid produce bilingual editions in combination with Warschewiczki, but they provide reproductions, more or less, of the edition by Commelinus, and Schmid takes over the comments of Bourdelotius. ${ }^{29}$ Gambara's Latin version of Longus, in turn, accompanies the Greek text in the editiones Commelinianae of the brothers Bonnvitius (Heidelberg, 1601 and 1611), and in the edition of Benjamin Gottlieb Boden (Leipzig, 1777). And concerning Achilles Tatius, della Croce's complete Latin version is reprinted next to the Greek text in the editio Commiliniana of 1601 and with the Greek text of Saumaise in 1640. But in the eighteenth century, even more curious examples of combining translations and editions come into existence. Notable is an edition in Luca (1781) of Xenophon of Ephesus: it reprints the Greek text next to a Latin translation of Cocchi's edition, alternating with a page with Salvini's Italian translation printed next to the French of Jourdan. The Glasgow edition of Heliodorus in 1753 reprints, according to Black (2011:356), the translation by Nahum Tate, except for the last two pages which are taken from the 1717 translation. And Antoine le Camus makes his own anonymous French translation of Longus and prints it next to the one by Amyot in 1757.

These combinations are the most obvious connections between editions and translations which can be seen in my bibliography, but the survey also allows us

\footnotetext{
${ }^{28}$ Sandy 1982:122-123.

${ }^{29}$ Rattenbury 1960:xlviii.
} 
to see another possible type of connection: dependency. The chronology permits us to see which translations preceded others, and might have functioned as source texts. Indeed, sometimes even the title betrays the sources from which they derive their translation: both William Burton and François de Belleforest copy the spelling “Achilles Statius" from their example, della Croce's complete Latin version, which, as Nakatani (2005:11-12) suggests, the Italian had taken over from the Suda. ${ }^{30}$ The success of some editions in reprints echoes their popularity as models for other translations. To give some examples, Amyot's Heliodorus is the foundation for the anonymous Spanish 1554 translation, and his Longus for the English paraphrase by Angell Daye. Della Croce's incomplete version of Achilles Tatius was the basis for the Italian translation by Ludovico Dolce and the French one by Philibert de Vienne, while the French version of Ravaud was the source for the anonymous German one in 1631, and the Italian one by Coccio for the Spanish one by Agreda y Vargas. Zschorn's German translation of Heliodorus is an important source for Eastern European translations. Instead of using the Latin of his countryman Warschewiczki, Andrzej Zacharzewski derives his Polish translation from Zschorn, and Zschorn's German is also the source for the Hungarian translation by Mihály Czobor. ${ }^{31}$ Warschewiczki's function as model can be derived in some cases because he frequently errs and, as a result, the translators using the Latin by Warschewiczki as source text make the same mistakes. In that respect, the English translation by Underdowne and the German one by Zschorn are quite faulty. ${ }^{32}$ A translation can also be based on several source texts. Thus, according to their preface, the English translators of Chariton based their work on the Italian of Giacomelli, Reiske's Latin, and occasionally on the original Greek text. We can also observe the opposite phenomenon, where apparently the existence of other translations was not known about. Thus, the title of a Latin translation of Heliodorus by the Hungarian György, "Nunc Primum In Latinam Linguam Conversi", is remarkable, because it claims to be the first Latin translation, as if suggesting the translator did not know of Warschewiczki's first Latin translation, nor of Crusius' recent version.

${ }^{30}$ For Burton's dependence on della Croce, see Nakatani (2005:13), and for that of Belleforest, see Calvet-Sebasti (2015:53).

${ }^{31}$ See for the Spanish one de Armas Wilson (2014:20), for Daye, among others, Hofmann (2011:109) and MacQueen (1990:265). For Dolce, see Gesner (1970:149) and Hofmann (2011:107); for de Vienne, see Nakatani (2005:10); for the German one, Nakatani (2005:18); for Vargas, see Gual (2011:192). See for Zacharzewski's translation Urbanowicz (2002) and Krzyźanowski (1984:248; 2012), for Czobor, see Rajka (1917:37-62).

${ }^{32}$ For Underdowne, see Gesner (1970:147) and de Armas Wilson (2014:20). For Zschorn, see Seeber (2017:514). 


\section{Combinations with other stories}

As mentioned under the history of their transmission, in the eighteenth century it becomes customary to print the Greek romances together. Though the brothers Bonnvitius were the first to publish Achilles Tatius together with Longus and Parthenius in 1601, their collection was an exception at that time. It was, however, already much more commonplace by then to print the Greek romances alongside other romances. These could be romances in a very general sense, as in a collection of love stories, including chivalric romances. Thus, in 1587 Zschorn's Aethiopica Historia is reissued as part of the Buch der Liebe by Sigmund Feyerband, together with medieval romances like Tristrant and Magelone. Or the volumes concern more specific combinations with other romances. The anonymous German translator of Achilles Tatius in 1631, for example, makes Leucippe and Clitophon the fourth part of the Theatri Amoris, a collection of German translations of French adaptations of Greek romance. ${ }^{33}$ The eighteenth-century collections of the Greek romances were not restricted to just those romances, and were often printed alongside other romances written in or translated into French, such as French chivalric or heroic romances, fairy tales, the Latin romances, and also some of the Byzantine romances. The latter does not surprise: as Nakatani (2005:18) states, throughout the entire early modern era, the Greek romances are often combined with other (ancient and modern) stories sharing a similar love theme (e.g. Parthenius's Erotica Pathemata is included in the editio princeps of Achilles Tatius), as well as with the Byzantine romances, because the Greek and Byzantine love stories are considered as one genre. The Dutch translation of Achilles Tatius by Van Nispen in 1652, for example, is printed together with Eustathius's Ismene and Isminias and Musaeus's Hero and Leander. And, in 1782, an anonymous French Xenophon is connected to Eustathius' Byzantine romance.

The combination with other stories in compilations tells us more about associations made between Greek romances and other texts, as well as about publishers' views on the romance. For example, the English translation of Heliodorus of 1717, in which the translator calls the Aethiopica the "Mother Romance of the World", is reprinted as the first book, a prominent place, in the Winter-evenings Entertainment, a collection of the best books ever written. This is a sign of the ongoing appreciation of Heliodorus, who is still considered the progenitor of novel writing. This aspect of the transmission is, however, relatively unexplored as yet. As Sandy (2008:307) remarks, Sanford's publication of his English Heliodorus together with Plutarchus was probably inspired by Amyot's famous trans-

${ }^{33}$ Möckel 2007:137-138. 
lations of both authors, but why did he also include the sayings of the philosophers? Why did Fraunce put the first book of the Aethiopica together with excerpts of pastoral love stories into hexameters?

To conclude, my expansion in time (up to 1799) and location (including Scandinavia, Ireland, and Eastern Europe) potentially opens the door to new insights. I have provided an overview of broad, changing tendencies throughout the early modern era, marking the late seventeenth century as a temporary breaking point and the eighteenth century as a period of transition, because of several shifts that occur during that time. My bibliography makes it possible to filter the literature's geographical dispersion across Europe over a wider area than was available before now, allowing a more complete picture of their distribution, as well as of their interconnections. Furthermore, I pointed out some peculiar (tendencies in) combinations among the lemmata themselves, as well as in combination with other stories, and I also disputed older findings by questioning alleged (re)prints. As I have suggested, the bibliography also allows us to identify opportunities for new research: to discover connections between the appearance of the Greek romances in print and the possible impact on the literature and art of the country where they are printed, to discover the dependency of one translation/edition on another, or to pay more attention to the associations made between stories.

\section{Bibliographic survey of the Greek romances in the early modern era}

I have ordered the editions and translations by Greek novelist (in order of rediscovery), and then, for each author, I list works in the classical languages (Greek, Latin, or both), followed by vernacular translations grouped alphabetically by language, and within each language, the works are listed chronologically. The information consists of the name of the editor and/or translator, title, place, year. Reprints are mentioned underneath the first publication, with additional information where the title or spelling changes, or when it is revised or reprinted in a larger compilation. Underneath the indubitable reprints, I put references to reprints in secondary literature which I consider as dubious because they cannot be found, in order to separate the uncertain from the certain reprints.

To show the source or the status of my data, I use the following symbols. An asterisk (*) designates that I have seen evidence of a work's existence with my own eyes, either a picture of the front page or a digitalised copy. Apart from editions available on Google Books, the catalogues (BSB, Gallica, USTC, ÖNB, 
Hungaricana) also sometimes provide digitalised copies. The Ilmenauer Discovery Tool contains microforms. An inverted question mark (i) indicates that I was unable to find the item myself, but that item was consulted by another scholar. In that case, it is either mentioned as such in a bibliography (Ferrini 1991 for Longus) or examined and/or quoted in one of the chapters or articles I have read. A lemma put between brackets ([...]) signifies that it was produced but not put into print, or only much later, as I illustrate with additional information in a footnote. The others I found in the catalogues I consulted, to which I refer in the footnotes. In addition to the catalogues, Nakatani's bibliography (Nakatani 2005:253-256) also mentions copies in libraries and reference numbers for Achilles Tatius specifically. When put between two daggers $(\dagger \ldots \dagger)$, the existence of the translation is uncertain.

\section{Heliodorus, Aethiopica}

\section{BILINGUAL EDITIONS (GREEK AND LATIN)}

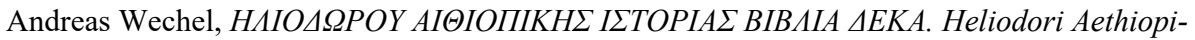
carum Historiarum liber primus, Parijs, $1558^{34}$.

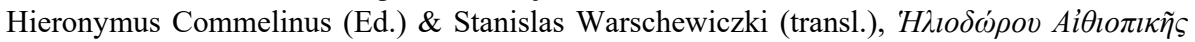

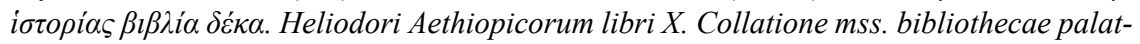
inae et aliorum emendati, \& multis in locis aucti, Heidelberg, 1596*.

— Reissued in Lyon: $1611^{*}, 1640^{*}$.

- According to Gesner (1970:159) reissued in Oberursel, 1601; Lyon, 1601.

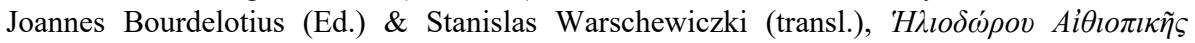

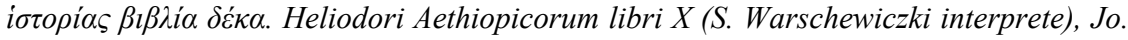
Bourdelotius emendavit, supplevit ac libros decem animadversionum adjecit, Paris, 1619*

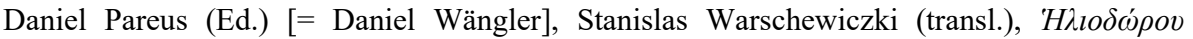

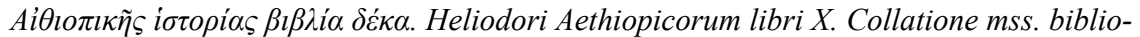
thecae palatinae et aliorum emendati, \& multis in locis aucti, atque in capita ordine distincti; cura et labore Danielis Parei, Frankfurt, 1631*.

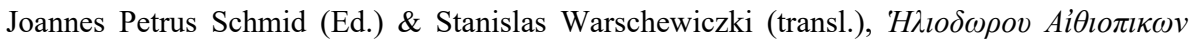

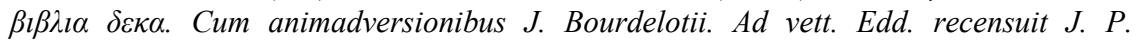
Schmidius, Leipzig, 1772*.

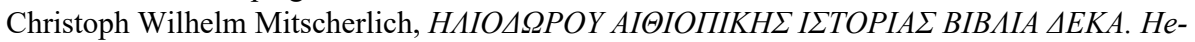
liodori Aethiopicorum libri decem. In Scriptores Erotici Graeci, Volume 2. Strasbourg: $1793 .{ }^{35}$

- Reissued in Strasbourg, 1797-8*.

\section{GREEK EDITIONS}

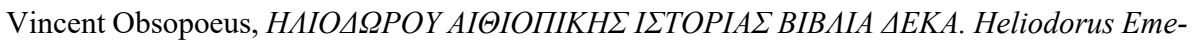
sus Historiae aethiopicae libri $X$, numquam antem in lucem editi, Basel, 1534*.

\footnotetext{
${ }^{34}$ See the ICCU.

${ }^{35}$ See the catalogue of the ÖNB.
} 


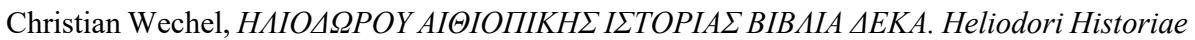
aethiopicae liber primus, numquam antem in lucem editi, Paris, $1551 * 36$

\section{LATIN TRANSLATIONS}

Renatus Guillonius [= René Guillon], Heliodori Aethiopicarum Historiarum liber primus. Renato Guillonio Vindocinensi interprete, Paris, 1552*.

- Reissued in Paris, $1557^{37}$.

Stanislaus Warschewiczki, Heliodori Aethiopicae historiae libri decem, nunc primum e Graeco sermone in latinum translati: Stanislao VVarscheuuiczki polono interprete. Adiectum est etiam Philippi Melanthonis de ipso autore, \& hac eiusdem conuersione, iudicium. Item locuples rerum ac uerborum memorabilium index, Basel: 1552*.

— Reissued in Antwerp: 1556*; Oberursel: 1601*; Leyden: 1637*.

- Many scholars mention a print in 1551. Pumprla mentions an edition in Antwerp in 1554 with a question mark as nr. 5704 in Pumprla, V. (1996). Soupis starých tiskì ve fondech Státní vědecké knihovny v Olomouci, Volume 5, Part 6. Státní vědecká knihovna.

Martin Crusius, Martini Crusii Aethiopica Heliodori Historice Epitome. Cum observationibus ejusdem. Omne tulit punctum, qui miscuit utile dulci. Ejusdem de parentibus suis narratio. Cum indice copioso, Frankfurt, 1584*.

[Enyedi György, Heliodori Aethiopicae Decem, Nunc Primum In Latinam Linguam Conversi Interprete Georgio Eniedino Transilvano R. S. C. Clarissimo etc. Anno Domini 1592, Hungary, 1592]..$^{38}$

This remained in manuscript form, now located in the Kolozsvári Unitárius Kollégium.

Gulielmo Cantero, Heliodorus. Veneri et cupidini humanae vitae conservatoribus suavissimis, Heliodori episcopi Tricensis Aethiopica amoris omnis et festivitatis delitiae sacra sunt, Leyden, 1637*.

\section{DANISH TRANSLATIONS}

Hans Paus, ${ }^{39}$ Chariclea en Athiopisk Princessis Besynderlige Aventures og Hoendelser. Skreven først paa Grask af Heliodoro Biskop udi Tricca, og nu på Dansk oversat af Paus. Historie om Theagenes og Chaciclea af Heliodore af Phoenicien, Copenhagen, 1746.

- According to Oeftering (1901:52), first printed in 1690 in Copenhagen.

${ }^{36}$ Dionisotti (1995:88) says that this Greek text was intended to accompany the Latin translation of Renatus Guillonius and has the date 1551, while the Latin of Guillonius has the date 1552. See Dionisotti, A.C. (1995). Claude de Seysell. In: M. Hewson Crawford and C.R. Ligota, eds., Ancient History and the Antiquarian: Essays in Memory of Arnaldo Momigliano. London: Warburg Institue, pp. 73-104.

37 The Ccfr mentions a copy of this reprint in the library of Besançon: http://ccfr.bnf.fr/portailccfr/jsp/public/index.jsp?record $=$ bmr\%3AUNIMARC $\% 3$ A $8945723 \&$ failure $=\% 2 \mathrm{Fjsp}$ $\% 2 \mathrm{Fpublic} \% 2 \mathrm{Ffailure}$.jsp\&action $=$ public direct view\&success $=\% 2 \mathrm{Fjsp} \% 2 \mathrm{Fpublic} \% 2 \mathrm{~F}$ index.jsp\&profile=public [Accessed 16 April 2018].

${ }_{38}$ For information on this translation, see Rajka (1917:9-16).

${ }^{39}$ A copy of 1746 is situated in Det Kongelige Bibliotek: https://rex.kb.dk/primo-explore/fulldisplay?docid=KGL01002157039\&context=L\&vid=NUI\&lang=en_US\&search scope $=$ KGL\&adaptor $=$ Local $\% 20$ Search $\% 20$ Engine $\&$ tab $=$ default tab\&query $=$ any,contains,Heliodor\&sortby $=1$ so01\&offset $=0$ [Accessed 21 March 2018]. 


\section{DUTCH TRANSLATIONS}

Charles Kina, De beschrijvinghe Heliodori vande Moorenlandtsche geschiedenissen: vervaet in thien boecken: Inhoudende de eerbare, cuysche, ende ghetrouwe liefde van Theagenes van Thessalien, ende Chariclea van Ethiopien, Amsterdam, 1610*.

- Ibid., De Tien Boecken van Heliodorus. Vervatende de ghetrouwe / langhdurige / cuysche liefde / van Theagenes Ridder van Thessalien, ende Chariclea Konigsdochter van Ethiopien. Nu op een nieu met Figuren verciert: Ende uyt het Griecx tot vermaeck ende leeringhe van alle Ionghe Minnaers vertaelt, Haarlem, 1634*.

Anonymous, ${ }^{40}$ De getrouwe liefde van de kuysche Theagenes en de zuyvere Cariceea. Nu nieuwlijx uyt 'et Griex en Latijn vertaalt, Amsterdam, 1659i.

J. Gentil, De Wonderlyke Liefde gefallen van Theagenes en Chariclea. Waarachtige Geschiedenis, in 't Grieksch beschreeven door Heliodorus en in zuyver Nederduytsch overgebracht door J. Gentil, 's Gravenhage, 1726*.

- Reissued in Leyden, 1731*.

\section{ENGLISH TRANSLATIONS}

James Sanford, The Amorous and Tragicall Tales of Plutarch. Whereunto is annexed the Hystorie of Cariclea \& Theagenes (gathered for the most part out of Heliodorus), and the sayings of the Greeke Philosophers, London, 1567*

Thomas Underdowne, An Athiopian Historie, written in Greeke by Heliodorus, no lesse wittie than pleasaunt. Englished by T. Underdowne, London: 1569?*

- Reissued in London, 1577*, 1587*, 1605*, 1606*

- According to Oeftering (1901:50), who mostly follows Hoffmann (1839), and Gesner (1970: 159) reissued in London, 1627.

Thomas Underdowne, revised and collated by William Barrett, Heliodorus his Aethiopian history: done out of Greeke, and compared with other translations in diuers languages. The arguments and contents of euery seuerall booke, are prefixed to the beginning of the same, for the better vnderstanding of the storie, London, 1622*.

Abraham Fraunce, The Countesse of Pembrokes Yvychurch. Conteining the Affectionate Life and Unfortunate Death of Phillis and Amyntas: that in a Pastorall [translated from Tasso]; this in a Funerall [translated from T. Watson]: Both in English Hexameters. (The Lamentation of Corydon, for the Love of Alexis, Verse for Verse Out of Latine [of Virgil]. The Beginning of Heliodorus His Ethiopical History.), London, 1591*.

- According to Oeftering (1901:50) reissued in London, 1592.

William Lisle, The Faire Aethiopian, dedicated to the King and Queene, by their Majesties most humble subject and servant, William Lisle, London, 1631*.

- Ibid., The famous historie of Heliodorus. Amplified, augmented, and delivered paraphrastically in verse; by their Majesties most humble subject and servant, William Lisle. Whereunto is added divers testimonies of learned men concerning the author. Together with a briefe summary of the whole history. Divided into tenne bookes ..., London, 1638*.

Anonymous and Nahum Tate, The Athiopian history of Heliodorus. In ten books. The first five translated by a person of quality, the last five by N. Tate, etc., London: 1686*.

${ }^{40}$ See also Pol, L.R. (1987). Romanbeschouwing in voorredes. Een onderzoek naar het denken over de roman in Nederland tussen 1600 en 1755. Deel 2: Teksten. Utrecht: H\&S. Available at: http://www.dbnl.org/tekst/pol_002roma02_01/pol_002roma02_01_0014.php [Accessed 2 March 2018]. 
- Ibid., The Triumphs of Love and Constancy: a romance. Containing the Heroick Amours of Theagenes and Chariclea. In ten books, London, 1687*.

- Ibid., Aethiopian adventures: or, the history of Theagenes and Chariclea. Written originally in Greek, by Heliodorus. In ten books. The first five translated by a person of quality, the last five by $N$. Tate. To which are prefixed, the testimonies of writers, ... concerning this work, Glasgow, 1753*.

C. G. [Charles Gildon], The adventures of Theagenes and Chariclia, a romance. Being the Rise, Progress, Tryals, and happy Success of the Heroic Loves of those Two Illustrious Persons. Wherein the following Histories are intermix'd. I. The Treacherous Slave; Or, Cruel StepMother. II. The Wandering Prelate. III. The Fighting Priest. IV. The Royal Adultress. With several other Curious Events. Written originally in Greek by Heliodorus Bishop of Heliodorus in the Fourth Century of Christianity; who chose to be depriv'd of his Bishoprick, rather than destroy this Book, design'd by Him for the Promotion of Virtuous Loves. In two volumes, London, 1717 *.

- Reissued in London, 1752* in Winter-Evenings entertainment. Consisting of the best novels and histories that have been written in most languages. Being such as, at the same Time they most agreeably amuse, enlarge the Ideas of the Mind, set Virtue before the Eyes of the Reader in all its Loveliness, and excite an almost irresistible Emulation of Great and Good Actions.

— The last two pages are reissued in $1753 *$ after the Glasgow edition of Nahum Tate's translation.

Anonymous, The adventures of Theagenes and Chariclea. A romance. Translated from the Greek of Heliodorus, London, 1789*.

\section{FRENCH TRANSLATIONS}

[Lancelot de Carle, Le premier livre d'Heliodore de l'histoire d'Aethiopie, translaté de grec en françois par Carle, manuscript in the royal library of Fontaineblau, between 1534 and 1547]. . $^{4}$

Jacques Amyot, L'Histoire aethiopique de Heliodorus, contenant dix livres, traitant des loyales et pudiques amours de Theagenes Thessalien et de Chariclea Aethiopienne, nouvellement traduite de Grec en Françoys, Paris: 1547*.

- Reissued ${ }^{42}$ in Paris: $1549^{*}, 1553^{*}, 1555,1559^{*}, 1560^{*}, 1570,1585,1596,1599$, $1609^{*}, 1614,1616^{*}, 1626$; Rouen: 1588*, 1596, 1607, 1609*, 1612; Lyon: 1559, 1575, $1579 *, 1584 *, 1589 *$.

- According to Gesner (1970:158) reissued also in Paris, 1575, 1583, 1611, 1613; Munich, 1553, 1596, 1613. Oeftering (1901: 47) mentions reprints in Munich, 1549, 1553; Paris, 1575, 1583, 1611.

Claude Collet, L'histoire éthiopique d'Heliodore, parte en dix livres, traitant des loyales et pudiques amours de Theagenes Thessalien et Chariclea Ethiopienne nouvellement traduite de grec en français par Claude Colet, Lyon, $1559 .{ }^{43}$

\footnotetext{
${ }^{41}$ See for information on this translation Plazenet 2002:249-250.

${ }^{42}$ See the ICCU and BNF, and the USTC for the sixteenth-century editions specifically with links to libraries and digitalised copies.

${ }^{43}$ See the ICCU for items in libraries.
} 
Claude Cartault, Histoire Aethiopicque d'Heliodore traictant des pudicques Amours de Theagenes Thessalien, et de Chariclea Aethiopienne, contenant dix livres. A esté nouvellement mise en vers françois, abregée en six livres, Auxerre, 1612.44

Paul Vallet, Les Adventures amoureuses de Theagenes et Cariclee. Sommairement descrite et representee par figures Dedié Au Roy Par Pierre Vallet son brodeur ordinaire Avec Privilege du Roy, Paris, 1613*.

Jean de Montlyard, Les Amours de Théagène et Chariclée, histoire éthiopique d'Héliodore, traduction nouvelle, Paris: $1620^{45}$.

- Reissued in Paris: 1622, 1623, 1626*, 1633*.

M. Maulnoury de La Bastille, Les Amours de Théagènes et Chariclée, traduction libre faite sur le grec d'Héliodore. Le Triomphe de la Raison, Amsterdam, 1716*.

Louis François de Fontenu, Amours de Théagènes et Chariclée, histoire Ethiopique, Amsterdam, $1727^{*}$.

— Reissued in Paris: 1727*, 1743*; Genève: 1782*.

— In Paris, $1785^{*}$ in the Bibliothèque universelle des Dames. Romans. Tom. 3.

— In Paris, 1796* in the Bibliothèque des romans grecs, traduits en français. Tome IV.

\section{GERMAN TRANSLATIONS}

Johannes Zschorn, Aethiopica historia. Ein schöne vnnd Liebliche Histori, von einem großmütigen Helden aus Griechenland vnd einer vberschönen Junckfrawen, eines Königs dochter der schwartzen Moren (der Jüngling The agenes vnnd die Junckfraw Chariclia ... Aus dem Griechischen ins Latin, vnd yetzundt newlich ins Teutsch bracht, gantz kurtzweilig vnd nutzlich zu lesen, Strasbourg: 1559*.

- Reissued $^{46}$ in Leipzig, 1597*, s.1. 1630.

- In Frankfurt, 1587 $i$ as part of the Buch der Liebe by Sigmund Feyerband.

- According to Oeftering (1901:49) reissued in Strasbourg, s.d., 1620; Frankfurt, 1562. According to Gesner (1970:158) also in Nurnberg, s.d.; Frankfurt, 1562, 1581; Bassea, 1580; Strasbourg, 1620.

- Ibid., Heliodori Historia Aethiopica. Ein schöne vnnd Liebliche Histori, von einem großmütigen Helden aus Griechenland vnd einer vberschönen Junckfrawen, eines Königs dochter der schwartzen Moren (der Jüngling The agenes vnnd die Junckfraw Chariclia ... Aus dem Griechischen ins Latin, vnd yetzundt newlich ins Teutsch bracht, gantz kurtzweilig vnd nutzlich zu lesen, Frankfurt: $1580^{*}$.

- Ibid., Heliodorus, oder seine sehr schöne liebliche nützliche Historie von Theagene und Chariclia, erstlich griechisch beschriben nachmahlen in Latin und Französisch, und jetzo auff das neuw in Teutsche Spraach mit fleiss übersetzt, Strasbourg, 1624.

Christian Wilhelm Agricola, Aethiopische Liebes- und Helden Geschichte aus dem Griechischen ... übersetzet durch M. C. W. A., Jena, 1750*.

Johann Nicolaus Meinhard, Theagenes und Chariklea, eine Aetheopische Geschichte in zehn Büchern. Aus dem Griechischen des Heliodorus übersetzt, Leipzig, 1767*.

${ }^{44}$ A copy is consultable in the Bibliothèque Mazarine.

${ }^{45}$ See for the 1620 edition the BNF: http://catalogue.bnf.fr/ark:/12148/cb39334807b [Accessed 21 March 2018], for the 1622 a copy in the Bibliothèque Municipale de Lyon: https://catalogue.bm-lyon.fr/ark:/75584/pf0000289749?posInSet=9\&queryId=70e05947ac9e-4d36-b937-a2f70392817b [Accessed 21 March 2018], and for the 1623 print the BNF: http://catalogue.bnf.fr/ark:/12148/cb339938302 [Accessed 21 March 2018].

${ }^{46}$ See for the 1624 and 1630 editions the Ilmenauer Discovery Tool. 


\section{HUNGARIAN TRANSLATIONS}

[Mihály Czobor (?), Theagenes és Chariclia, between 1600 and 1604]. - This translation was not printed until 1996 in Budapest by Peter Köszeghy.

István Gyöngyösi, Uj életre hozatott Chariclia, Avagy a' Chariclia ritka példájú, és olvasásra kedvet - adó historiájának némelly régi versek rongyábúl, és azoknak sok fogyatkozásibúl újjabb, és jobb rendben vétele. A' mellyet a verseket örömest olvasó némelly jó urai kivánságára, és kedvéért beteges állapottyában nem kis munkával vitt végben Gyöngyösi István, Löcse, $1700 .{ }^{* 47}$

— Reissued in Budán: 1733*, 1763*.

András Dugonics, A szerecsenek. Újjabb életre hozta Dugonics András kiraji oktato. Másadik köniv. Áfrikai esetek, Pozsony, 1798*. ${ }^{8}$

\section{ITALIAN TRANSLATIONS}

Hieronymus Bossi, I primi cinque canti d'Eliodoro in ottavo rima, Milan, $1557 .{ }^{49}$

Leonardo Ghini, Historia di Heliodoro delle cose ethiopiche. Nella quale fra diuersi, compassioneuoli auenimenti di due amanti, si contengono abbattimenti, discrittioni di paesi, e molte altre cose utili e diletteuoli a leggere. Tradotta dalla lingua greca nella thoscana da messer Leonardo Ghini. Con la tavola di tutte le cose notabili, Venice: 1556*.

- Reissued ${ }^{50}$ in Venice: 1559*, 1560*, 1586, 1587*, 1588*, 1611*, 1623, 1633, 1636*. On the title page of the edition of 1556, 1586, 1588 and 1623, the name of the author is misprinted as Glinci.

- According to Gesner (1970: 159) and Oeftering (1901: 50) also reissued in Venice, 1568 .

- Ibid., La Dilettevole Historia di Heliodoro. Nella quale oltre diversi compassioneuoli auenimenti di due amanti, si contengono vari accidenti d'Amore. Con la tavola di tutte le cose notabili. All' illustre sig. Giulio Pallavicino, Genova, 1582*.

\section{POLISH TRANSLATIONS}

Andrzej Zacharzewski, Historia murzyńska o nadobnym Teagenie i o pięknej Charykliej, Vilnius, 1606.

Only the 1606 edition published in Vilnius - Lithuania and Poland then being one nation survives, presently located in the Čartoriskių Library in Krakau. ${ }^{51}$ According to Urbanowicz (2002:300) and Krzyźanowski (1984:248; 2012), Zacharzewski published it for the first time in 1590 in Vilnius and it was reissued in 1663 in Krakau, but no proof for that exists.

${ }^{47}$ Digitalised copy available at: https://rmk.hungaricana.hu/en/RMK I 1564/?query= $=[$ Accessed 21 March 2018].

${ }^{48}$ Available at http://reader.digitale-sammlungen.de/de/fs 1/object/display/bsb10048087 00001.html [Accessed 22 February 2018].

${ }^{49}$ See USTC.

${ }^{50}$ For references to the libraries where to find them, see the catalogue of the ICCU. For the 1633 edition, however, see the BNF: http://catalogue.bnf.fr/ark:/12148/cb30589060x [Accessed 21 March 2018].

${ }^{51}$ Ivanovič, M. (1998). Polska książka na Litwie w XVII w. Vilnius: Lietuvos Nacionalinè Martyno Mažvydo biblioteka, Bibliografijos ir knygotyros centras, p. 70; Urbanowicz (2002:300). 


\section{SPANISH TRANSLATIONS}

[Francisco de Vergara, 1545]. ${ }^{52}$

Anonymous, Historia Ethiopica. Trasladada de Frances en vulgar Castellano por un segreto amigo de su patria y corrigida segun el Griego por el mismo, dirigida al ilustrissimo señor, el señor Don Alonso Enrriquez, Abad dela villa de Valladolid, Antwerp, 1554*.

- Reissued $^{53}$ in Salamanca, 1581.

- According to Gesner (1970:158) also reissued in Madrid, 1615.

- Ibid., La muy deleytosa, y agradable historia de los afortunados amantes Theagencs y Chariclea, Toledo, 1563.

Fernando de Mena, La historia de los dos leales amantes Theagenes y Chariclea. Trasladada agora de nuevo de Latin en Romance por Fernando de Mena, Alcala de Henares: 1587*.

- Reissued in Barcelona: 1614*; Paris: 1616*; Madrid: 1787*.

- According to Gesner (1970:159), also reissued in Barcelona, 1615.

- Reissued on behalf of Pedro Pablo Bogia as Historia Etiopica de los amores de Teagenes y Cariclea. Añadida la vida del autor, y una tabla de sentencias, etc., Madrid, 1615*.

Fernando Manuel de Castillejo, La nueva Cariclea, ó nueva traduccion de la novela de Theagenes y Chariclea, que con titulo de Historia Etiopia escrivió el antiguo Heliodoro, Madrid, 1722*.

\section{Achilles Tatius, Leucippe and Clitophon}

\section{BILINGUAL EDITIONS (GREEK \& LATIN)}

Juda and Nicola Bonnvitius (eds), Achillis Statii de Clitophontis et Leucippes amoribus libri viii. Longi Sophistae de Daphnidis et Chloes amoribus libri iv. Parthenii Nic. de amatoriis affectibus l. I, Heidelberg: 1601*.

- Reissued in Heidelberg, 1606*.

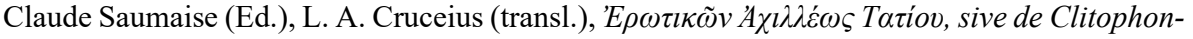
tis et Leucippes amoribus libri VIII, ex editione Cl. Salmasii, Leyden, 1640*.

Claude Saumaise, Benjamin Gottlieb Lorenz Boden, Johann Benedict Carpzov, T. B. Berger,

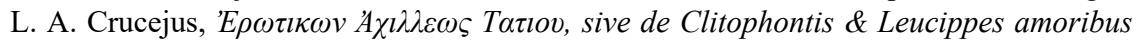
libri VIII, ex bibliotheca Cl. Salmasii, Leipzig, 1776*.

Christoph Wilhelm Mitscherlich, AXI $\Lambda \Lambda$ E $\Omega \Sigma$ TATIOY A $\Lambda$ E $\Xi A N \Delta P E \Omega \Sigma$ EP $\Omega T I K \Omega N$ BIB $\Lambda$ IA H. Achillis Tatii Alexandrini de Clitophontis et Leucippes amoribus libri VIII graece et latine, textum recognovit, selectamque lectionis varietatem adjecit Christ. Guil. Mitscherlich professor Gottingensis, Zweibrücken, 1792*.

\section{LATIN TRANSLATIONS}

Luigi Annibale della Croce, Achillis Tatii narrationis fragmentum e graeco in latinum conversum, L. Annibale Cruceio interprete, Lyon, 1544*.

- Ibid., Achillis Statii Alexandrini de Clitophontis \& Leucippes amoribus libri VIII, e Grocis Latini facti à L. Annibale Cruceio, Basel: 1554*.

— Reissued in Cambridge: 1587, 1589?*; Bergamo?, 1587*; Leyden, 1590.

\footnotetext{
${ }^{52}$ Gesner 1970:147-148; Gual 2011:193; see for more information on what happened to the manuscript footnote 46 of Plazenet 2002:250.

${ }^{53}$ All editions can be found on the USTC.
} 
- According to Gesner (1970:154) first printed in Bergamo in 1552. According to Brehm, G.N. (1800). Bibliographisches Handbuch der gesammten neuer, sowohl allgemeinen als besondern griechischen und römischen Litteratur: Besondere griechische Schriftstellerkunde, Volume 2. Leipzig: Caspar Fritsch, p. 1, it was reissued in Cologne in 1581 , but he suggests it in a doubtful tone ("so viel wir wissen").

\section{DUTCH TRANSLATIONS}

Adriaan van Nispen, De Grieksche Venus: vertoonende de beroemde vryagien van Klitophon en Leucippe, Ismenias en Ismene, Leander en Hero. Vyt 't Grieksch vertaald, en by een gevoegt, door Adr. van Nispen, Dordrecht, 1652*.

\section{ENGLISH TRANSLATIONS}

William Burton, The Most Delectable and Pleasaunt History of Clitophon and Leucippe. Written first in Greeke, by Achilles Statius an Alexandrian: and nowe newly translated into English, By W.B. Whereunto is also annexed the argument of euery booke, in the beginning of the same, for the better vnderstanding of the historie, London, 1597*.

Anthony Hodges, The Loves of Clitophon and Leucippe. A most elegant History, written in Greeke by Achilles Tatius: And now Englished, Oxford, 1638*.

Anonymous, The amours of Clitophon and Leucippe. Illustrated, in six novels. Viz. I. The Force of Love described. II. The Disappointed Bride. III. The Distressed Lovers. IV. Virtue its own Reward. V. The Lascivious Widow. VI. The Happy Consummation. Written in Greek, by Achilles Tatius. Now first rendred into English, London, 1720*.

\section{FRENCH TRANSLATIONS}

Philibert de Vienne, Les Devis amoureux, traduictz nagueres de grec en latin, \& depuis de latin en françois, par l'Amoureux de vertu, Paris, $1545^{54}$.

Jacques de Rochemaure, ${ }^{55}$ Les quatres derniers livres des propos amoureux contenans le discours des amours et mariage du seigneur Clitophant et damoiselle Leusippe, Traduitz de grec en langue latine et depuis nouvellement remitz en langue Françoyse, Lyon: 1556.

- Ibid., Propos amoureux contenans le discours des amours et mariage du Seigneur Clitophant et damoiselle Leusippe. Traduiz de Grec en langue Latine et Tusquane et dupuis nouvellement remitz en langue Francoyse, Lyon: 1572*.

- Reissued in Lyon, 1573. ${ }^{56}$

B. Comingeois [= François de Belleforest], Les amours de Clitophon et de Leucippe: escris jadis en grec par Achilles Statius (sic) Alexandrin, et depuis mis en latin par L. Annibal (Croceius) Italien, et nouvellement traduits en vers françois, Paris: 1568.

- Reissued ${ }^{57}$ in Paris, $1575^{*}$; Lyon, 1586.

- According to Gesner (1970:155) also reissued in Lyon in 1575.

A. Rémy [= Abraham Ravaud], Les amours de Clitophon et Leucippe tirées du grec d'Achille Tatius, Alexandrin, Paris, 1625 .

\footnotetext{
${ }^{54}$ See copy BNF: RES P-Y2-3137. The BNF also comments on the attribution: http://catalogue.bnf.fr/ark:/12148/cb35766717m [Accessed 21 March 2018].

55 Spelled Roquemaure by Jouanno (2015:164), Rochemore by Calvet-Sebasti (2015:5).

${ }^{56}$ See copy BNF: RES-Y2-1267 for the 1573 edition, and the USTC for a reference to the 1556 edition.

${ }^{57}$ See catalogue BNF for the editions.
} 
Jean Baudouin, Les Amours de Clytophon et de Leucippe. Traduction nouvelle, tirée du grec d'Achilles Tatius et divisée en huict livres, avecque des Argumens, \& des Figures en taille douce., Paris, 1635*.

Louis-Adrien Du Perron de Castera, Les Amours de Leucippe et de Clitophon, traduits du grec d'Achile Tatius, Amsterdam, 1733*.

- Reissued in La Haye, 1735*.

- In Paris, 1785* in the Bibliothèque universelle des Dames. Romans. Tom. 5.

- In Paris, 1797* in the Bibliothèque des romans grecs, traduits en français, vol. I.

Charles-Philippe de Monthenault d'Egly, Les Amours de Clitophon et de Leucippe, traduction libre du grec d'Achilles Tatius, avec des notes, par le sieur $D^{* * *} D^{* * *}$, Paris, 1734.

- Reissued $^{58}$ in La Haye, 1735.

\section{GERMAN TRANSLATIONS}

$\dagger$ David Wolstand, Lustgarten der Liebe von steter brennender Liebe zweyer Liebhabenden jungen Personen Daphnidis und Chloe zu Mytilenen von Longo Sophista beschrieben, aus den Griechisch verteuscht, Frankfurt, 1615†.

Anonymous, Theatri Amoris oder Schawplatz der Liebe Vierter Theil. Darinnen beschrieben die sehr artliche vnd ergetzliche Histori von keuscher beständiger vnd durch Mancherley seltzame Anstoeß treeflich bewehrter Liebe Clitophonis vnnd Leucippe, Frankfurt: 1631i. - Reissued in Frankfurt, 1644. ${ }^{59}$

$\dagger$ Anonymous, Achilles Tatius Historie der Liebe des Clitophons und der keuschen Leucippe. Aus dem Griechischen, Frankfurt, $1670 \dagger$.

- Nakatani (2005:18) admits that he did not see it and I was not able to find it myself, but some nineteenth-century books mention this translation. ${ }^{60}$

David Christoph Seybold, Liebesgeschichte des Klitophon und der Leucippe aus dem Griechischen des Achilles Tatius übersetzt, Lemgo, 1772*.

\section{HUNGARIAN TRANSLATIONS}

Joannes Festus, ${ }^{61}$ Igen szép História, az Geöreögh Clitophonnak és Leucip[p]enek egymáshoz való hivséges Szerelmekrül [Leucippe és Clitophon széphistóriája], Kassa, 1620*.

— reissued $^{62}$ in Löcse, 1631-1632.

${ }^{58}$ See catalogue BNF for both editions.

${ }^{59}$ See for both editions the Ilmenauer Discovery Tool.

${ }^{60}$ So does Hoffmann (1839:3); Schincke, J.C.G. (1838). Handbuch der Geschichte der griechischen Litteratur für den Gymnasial- und Selbstunterricht: mit besonderer Rücksicht auf L. Schaaff's Encyklopädie der classischen Alterthumskunde. Vierte Ausgabe. 1. Bd. 1 . Abth. Geschichte der griechischen Litteratur. Magdeburg: Wilhelm Heinrichshofen, p. 579; Jacob, F. (1821). Achillis Tatii Alexandrini De Leucippes et Clitophontis amoribus libri octo. Leipzig: In Bibliopolio Dykiano, p. 1xiv.

${ }^{61}$ According to Kiss (2017:266), however, the author is anonymous and the date ca. 1600 .

${ }^{62}$ Information in Hungarian about as well as a link to a digitalised fragment of this translation are available on this website: http://mek.oszk.hu/15300/15397/cimkes.html [Accessed 21 March 2018]. See for both editions https://rpha.oszk.hu/id/4019 [Accessed 22 March 2018]. 


\section{ITALIAN TRANSLATIONS}

Ludovico Dolce, Amorosi ragionamenti. Ne i quali si racconta un compassioneuole amore di due amanti, tradotti per M. Lodouico Dolce, da i fragmenti d'uno antico scrittor greco: \& di nuouo corretti \& ristampati, Venice: $1546 *$.

- Reissued in Venice, 1547*.

Francesco Angelo Coccio da Jano, Achille Tatio Alessandrino Dell' amore di Leucippe et di Clitophonte nuovamente tradotto dalla lingua greca, Venice: 1551*.

— Reissued in Venice, 1560*, 1563*, 1578*, 1608*; Florence, 1598*, 1617*.

- According to Gesner (1970:154) it was first printed in 1550 in Venice and also reissued in Venice: 1576, 1600, 1617, and Florence, 1599. Nakatani (2005:11) also mentions the reprints of Florence, 1599 and Venice, 1600. Hofmann, however, says: "Eine Ausg. von 1599 existirt nicht" (Hoffmann 1839:5).

- Ibid., Amorosi avvenimenti di due nobilissimi amanti. Dal Greco tradotti nella lingua Italiana per Francesco Angelo Coccio, Venice, 1568*; Treviso, 1600*.

\section{SPANISH TRANSLATIONS}

Diego de Agreda Y Vargas, Los mas fieles amantes, Leucipe y Clitofonte, historia griega por Aquiles Tacio Alexandrino, traduzida, censurada, y parte compuesta por don Diego de Agreda Y Vargas, Madrid, 1617*.

[Francisco de Quevedo and Pellicer de Ossau Salsa y Tovar, seventeenth century]. ${ }^{63}$

\section{Longus, Daphnis and Chloe}

\section{BILINGUAL EDITIONS (GREEK \& LATIN)}

Hieronymus Commelinus (Ed.), \& Lorenzo Gambara (transl.), АОГГОҮ ГОФІГТОY ПОIMENIKSN ИОГОI $\triangle$. De rebus pastorum seu, de castis Daphnidis et Chloes amoribus libri quatuor. Item Laurentii Gambarae Expositorum ex Longo libri IIII. Heroice carmine liberius redditi, Heidelberg, 1601*.

Juda and Nicola Bonnvitius (eds), Achillis Tatii de Clitophontis et Leucippes amoribus libri viii. Longi Sophistae de Daphnidis et Chloes amoribus libri iv. Parthenii Nic. de amatoriis affectibus l. I, Heidelberg: $1601^{*}$.

- Reissued in Heidelberg, 1606*.

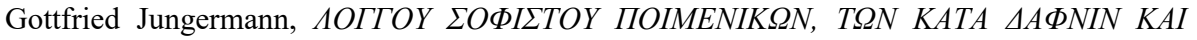
X $1 O H N$ BIBAIA TETTAPA. Id est, Longi Sophistae Pastorialium, de Daphnide et Chloe, libri quatuor. Gothofredus Iungermanus recensuit, in Latinum sermonem vertit, \& notas addidit, Hanau, 1605*.

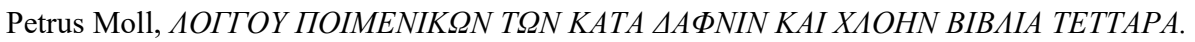
Longi Pastoralium de Daphnide et Chloe libri quattuor. Petrus Moll Snecanus, J.V.D. \& Gr. Ling. Profess. Ord. in Acad. Franek. Frisior. recensuit, in Latinum sermonem vertit, notis \& animadversionibus illustravit, Franeker, 1660*.

Johan Stephan Bernard, Longi Pastoralium, de Daphnide et Chloë, Libri quatuor. Graece et Latine. Editio nova ..., Paris, 1754*.

Benjamin Gottlib Lorenz Boden, Rafaello Colombani, Gottfried Jungermann, Petrus Moll, Lo-

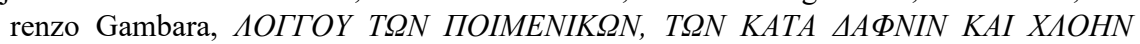
BIBAIA 4. Longi Pastoralium de Daphnide et Chloe Libri IV curavit varietatem lectionis

${ }^{63}$ Nakatani 2005:18. 
ac notas R. Columbanii G. Jungermani P. Molli et suas cum Laurentii Gambarae Expositis addidit M. Beni. Gottlib Laur. Boden Prof. Poes. Ord. Apud Vitebergenses Lipsiae, Leipzig, $1777^{*}$.

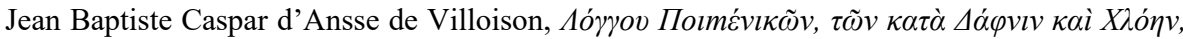

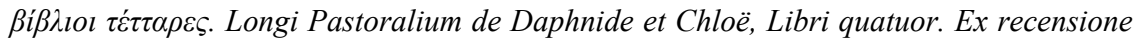
\& cum Animadversionibus Johan.-Baptistae Casparis d'Ansse de Villoison, Regiae Inscriptionum Academiae Paris..., Paris, 1778*.

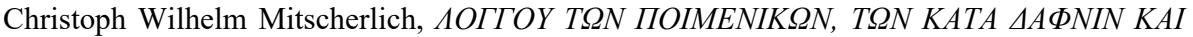

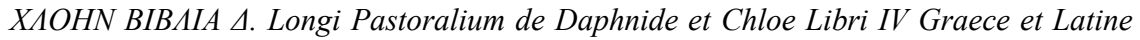
Accedunt Xenophontis Ephesiacorum de amoribus Anthiae et Abrocomae Libri V Textum recognovit, selectamque lectionis varietatem adiecit Christ. Guil. Mitscherlich Professor Gotingensis, in: Scriptores Erotici Graeci, Volumen tertium Longum et Xenophontem Ephesium continens, Zweibrücken, 1794*.

\section{GREEK EDITIONS}

Rafaello Columbani, АОГГОҮ TQN ПОIMENIKSN, TQN KATA $\triangle A \Phi N I N$ KAI XАOHN BIBAIA TETTAPA. Longi Pastoralia de Daphnide et Chloe libri quattuor. Ex bibliotheca Aloisij Alamannij, Florence, 1598*.

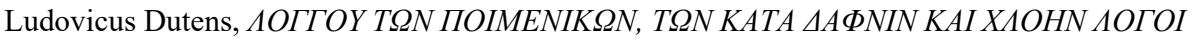
TETTAPE $\Sigma$. Recensuit Ludovicus Dutens, Paris, 1776*.

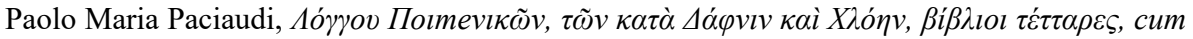
Proloquio de Libris Eroticis Antiquorum, Parma, 1786*.

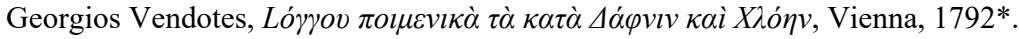

\section{LATIN TRANSLATIONS}

Lorenzo Gambara, Laurentii Gambarae Expositi. Ad illustrissimum Antonium Perenottum Cardinalem Granuellanum, Naples, 1574*.

— Reissued in Rome: 1581*.

- Other alleged reprints are mentioned in the introduction, under "Alleged editions".

\section{DUTCH TRANSLATIONS}

Anonymous, De herderlyke liefde-gevallen van Daphnis en Chloé, Amsterdam, 1744*.

\section{ENGLISH TRANSLATIONS}

Angell Daye, Daphnis and Chloe, excellently describing the weight of affection, the simplicitie of love, the purport of honest meaning, the resolution of men, and the disposition of Fate, finished in a pastorall, and interlaced with The shepherd's holidaie, London, 1587*.

George Thornley, Daphnis and Chloe. A most sweet and pleasant pastoral romance for young ladies. By Geo. Thornley, Gent., London, 1657*.

James Craggs, The pastoral amours of Daphnis and Chloe. Written originally in Greek by Longus, and Translated into English. Adorn'd with cutts., London: $1719 .{ }^{64}$

- Reissued in London, 1720*.

- Ibid., The pastoral amours of Daphnis and Chloe. In Four Books. Written originally in Greek by Longus. Translated into English by James Craggs Esq., London, 1733*.

${ }^{64}$ For the 1719 edition, see the Ilmenauer Discovery Tool. 
- Ibid., The pastoral amours of Daphnis and Chloe. A Novel. Written originally in Greek by Longus. And translated into English, London, 1763*.

- Ibid., The pastoral amours of Daphnis and Chloe. A Novel. Written originally in Greek by Longus. And translated into English by James Craggs, Esq., London, 1764*.

- Ibid., The Power of Love; or the Lives and Pastoral Amours of Daphnis and Chloe. With the Shepherds Calendar, \& $c$., Dublin, $1763 .{ }^{65}$

\section{FRENCH TRANSLATIONS}

Jacques Amyot, Les amours pastorales de Daphnis et de Chloé, escriptes premièrement en grec par Longus, et puis traduictes en françois, Paris: 1559*.

- Reissued ${ }^{66}$ in Paris: 1609 $i, 1716_{i}, 1717^{*}, 1731,1780_{i}, 1784_{i}, 1796^{*}$; Amsterdam: 1716i, 1734i, 1749*, 1750*, 1794; La Haye: 1764*; Bouillon, 1776*; Genève, 1777*; Versailles, 1784 $i$; Londres (Paris?): 1779*, 1780*; s.1. [Paris?], 1714 $i, 1716,1718^{*}$,

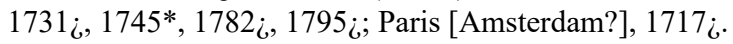

- Ferrini (1991:122-133) mentions some reprints she was not able to see herself, but that are mentioned elsewhere: in Paris, 1712, 1715, 1722, 1785; Londres, 1764; Lille, 1792.

- Ibid., Histoire des pastorales et bocageres amours de Daphnis et de Chloé traduite de Grec en François, Paris: 1594.

- Reissued in Paris: 1596, 1609 ¿; Rouen, $1599 .{ }^{67}$

- Reissued in Paris, 1797* in the Bibliothèque des romans grecs, trad, en fr. Vol. VI.

- Plazenet (1997:695) also mentions one in Paris, 1592.

Jacques Amyot \& Dame Louise Labé Lyonnoise, Histoires et amours pastoralles de Daphnis et Chloé. Ensemble un débat judiciel de Folie et d' amours, Paris, 1578;.

Pierre Marcassus, Les Amours de Daphnis et Cloé, Paris, 1626i.

Anonymous, Les amours pastorales de Daphnis et de Chloé. Avec Figures, Paris, 1718*.

Amyot \& Anonymous (Antoine Le Camus), Les Amours Pastorales de Daphnis et de Chloé, par Longus. Double Traduction du Grec en François, de Mr. Amiot et d'un Anonime, mises en parallele ..., Paris, $1757 i$.

- Ferrini (1991:127) mentions that Le Camus probably made already a translation in 1754 in Paris.

Anonymous, Les amours de Daphnis et Chloe: Avec figures par un eleve de Picart, Amsterdam: 1749 .

- Reissued in Amsterdam, 1750 $;$; London, 1764*.

François-Valentin Mulot, Daphnis et Chloé, in: Bibliothèque Universelle des Dames. Romans. Tome quatrième, Mithylène: $1783 i$.

- Reissued in Paris: $1785,{ }^{68} 1795 i$.

Pierre Blanchard, Les amours pastorales de Daphnis et de Chloé. Traduction nouv., par Pierre $B^{* * *}$, Paris, 1798 .

Jean François Debure de Saint-Fauxbin, Les amours pastorales de Daphnis et de Chloé, Paris: $1787 i$.

- Ferrini (1991:131) mentions a possible earlier version in Paris, 1786.

\footnotetext{
${ }^{65}$ See as with all English translations the catalogue of the BL.

${ }^{66}$ See the catalogue of the BNF.

${ }^{67}$ See the USTC for the sixteenth-century editions.

${ }^{68}$ See for the 1785 edition the BNF: http://catalogue.bnf.fr/ark:/12148/cb41007969r [Accessed 21 March 2018].
} 


\section{GERMAN TRANSLATIONS}

Friedrich Grillo, Daphnis und Chloe, aus den griechischen des Longus, Berlin, 1765*.

\section{ITALIAN TRANSLATIONS}

Giovanni Battista Manzini, Gli amori innocenti di Dafni e della Cloe. Favola Greca, descritta in Italiano dal commendator D. Gio. Battista Manzini. Al Potentissimo, \& Inuitissimo imperadore Ferdinando III, Bologna: 1643*.

- Ferrini (1991:95) doubts the existence of a reprint in Bologna, 1647.

Gasparo Gozzi, Gli amori Pastorali di Dafni e Cloe descritti da Longo Graeco ora per la prima volta volgarizzati, Venice, $1766 .{ }^{69}$

- Reissued in Paris, 1781*; Londra, 1786*.

- In Londra, 1792* reissued together with Salvini's translation of Xenophon.

- In Venice, 1794* in Opere in versi e in prosa del conte Gasparo Gozzi Veneziano. Tomo undecimo.

Annibal Caro, Gli amori Pastorali di Dafni e di Cloe di Longo Sofista Tradotti dalla lingua Greca nella nostra Toscana dal Commendatore Annibal Caro [1538]. ${ }^{70}$

- First printed in Crisopoli, 1786*.

— Reissued in Crisopoli, 1793/1794? ¿; Londra: 1786*, 1794. ${ }^{71}$

\section{SPANISH TRANSLATIONS}

Damasio de Frías y Balboa, Lidamarte de Armenia, s.l. [Spain]:1568.$^{72}$

- Reissued in s.1. [Spain], 1590i.

\section{Xenophon of Ephese, Ephesiaca}

\section{Multilingual editions (GReEK \& LAtin)}

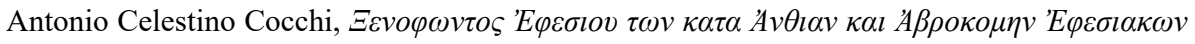
$\lambda o \gamma o r$ $\pi \varepsilon v \tau \varepsilon$. Xenophontis Ephesii Ephesiacorum libri $V$ de amoribus Anthiae et Abrocomae. Nunc primum prodeunt e vetusto codice bibliothecae monachorum Cassinensium Florentiae, cum latina interpretatione Antonii Cocchii Florentini, London, 1726*.

- Ibid., Xenophontis Ephesii Ephesiacorum libri V. de rebus Anthiae et Abrocomae Interprete Antonio Cocchio Florentino, cum animadversionibus Frid. Ludov. Abreschii, Gratiani de S. Bavone, et Tiberii Hemsterhusii. Curante E.P. qui et suas notas et emendationes adjecit, in usum serenissimi principis, \&c.\&c, London, 1760?*.

Baron Aloys Emmerich von Locella, Xenophontis Ephesii de Anthia et Habrocome Ephesiacorum libri V. Graece et Latine Recensuit supplevit emendavit Latine vertit adnotationibus aliorum et suis illustravit indicibus instruxit Aloys Emeric. Liber Baro Locella, Vienna, 1796*.

${ }^{69}$ See for this edition the ICCU.

${ }^{70}$ According to Cozad (2013:129), Caro's translation probably did not circulate in his own age, but Hofmann (2011:108) suggests that it was known in manuscript form during his lifetime among his friends and the literate circle of cardinal Alessandro Farnese in Rome. In the eighteenth century it is rediscovered and finally printed.

${ }^{71}$ See for Londra 1794 the ICCU.

${ }^{72}$ See Cozad (2013) for the translated/adapted lines of Longus in this chivalric romance. 
Christoph Wilhelm Mitscherlich, АОГГОY TQN ПОIMENIKSN, TQN KATA $\triangle A \Phi N I N$ KAI XАOHN BIBAIA 4. Longi Pastoralium de Daphnide et Chloe Libri IV Graece et Latine Accedunt Xenophontis Ephesiacorum de amoribus Anthiae et Abrocomae Libri V Textum recognovit, selectamque lectionis varietatem adiecit Christ. Guil. Mitscherlich Professor Gotingensis, in: Scriptores Erotici Graeci, Volumen tertium Longum et Xenophontem Ephesium continens, Zweibrücken, 1794*.

\section{Multilingual editions (Latin, italian, French)}

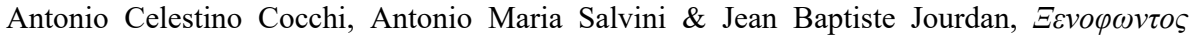

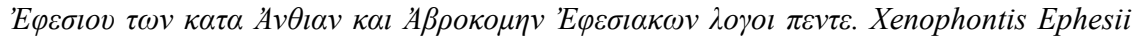
Ephesiacorum libri V. De amoribus Anthiae et Abrocomae. Accedit versio latina Antonii Cocchi, italica Antonii Salvini et gallica D. J., Luca, 1781*.

\section{LATIN TRANSLATIONS}

Angelo Poliziano, Miscellanea Centuria Prima, Florence, 1489*.

- Reissued $^{73}$ in Paris, 1511* and Basel, 1524 as Miscellanea Centuria una, and Basel, 1522* as Angeli Politiani Miscellaneorum Centuria Una.

- Reissued in Venice, 1502* and 1508; on behalf of Marco Antonio Sabellico in In hoc volumine haec continentur ... Angeli Politiani Miscellaneorum Centuria Una.

- Reissued in collections of Poliziano's works: in Venice, 1498* and in Florence or Brescia in 1499* in Omnia Opera Angeli Politiani, et alia qaedam lectu digna, quorum nomina in sequenti indice videre licet; in Paris, 1512*, 1519* in Omnium Angeli Politiani Operum (quae quidem extare novimus) Tomus Prior; in Lyon, 1536 in Angeli Politiani Opera. Quorum Primus Hic Tomus Complectitur Epistolarum Libros XII. Miscellaneorum Centuriam I. Omnia Iam Recens a Mendis Repurgata; in Basel, 1553* in Angeli Politiani Opera, quae quidem extitere hactenus, omnia, longe emendatius quam usquam antehac expressa: quibus accessit Historia de Conjuratione Pactiana in Familiam Medicam; in Antwerp, 1565i, and in Antwerp, 1567 $i$ with a slightly different title, first printed in Operum tomus primus, Epistolarum lib. XII ac Miscellaneorum Centuriam I complectens, second as Epistolarum libros XII. Miscellaneorum Centuria I.

— According to Gesner (1970:162) reissued in Brescia, 1496 instead of 1499.

\section{ENGLISH TRANSLATIONS}

John Rooke, Xenophon's Ephesian History: Or the Love-adventures of Abrocomas and Anthia. in Five Books. Translated from the Greek. by Mr. Rooke, London, 1727*.

\section{FRENCH TRANSLATIONS}

Jean Baptiste Jourdan, Les Ephésiaques de Xénophon Éphésien, ou les Amours d'Anthie et d'Abrocomas, traduits en françois, Paris: 1736*.

- Reissued in Paris, 1748* as Amours d'Abrocome et d'Anthia, histoire Éphésienne, traduite de Xenophon, par M. J.***.

— In Paris, $1785^{*}$ in the Bibliothèque Universelle des Dames. [Romans, tom. 3.].

- In Paris, 1797* in the Bibliothèque des Romans Grecs, etc. Tom. 7.

73 The editions are consulted by Pontani in the introduction of Poliziano, A. \& Pontani, F.M. (Ed.) (2002). Angeli Politiani Liber epigrammatum Graecorum. Roma: Edizioni Di Storia E Letteratura. 
Anonymous, Les Amours d'Ismene et d'Ismenias, suivis de ceux d'Abrocome \& d'Anthia, Genève, $1782 *$.

\section{GERMAN TRANSLATIONS}

Gottfried August Bürger, Anthia und Abrokomas. Aus dem Griechischen., Leipzig, 1775*

Johann Andreas Häuslein, Etwas von Ephesus, oder Geschichte eines iungen Ehepaars, griechisch beschrieben von Xenophon von Ephesus, übersetzt durch $H^{* * *}$, Ansbach, 1777*.

\section{ITALIAN TRANSLATIONS}

Antonio Maria Salvini, Di Senofonte Efesio, degli Amori di Abrocome e d'Anthia libri V. Tradotti da A. M. Salvini, London: 1723*.

- Reissued $^{74}$ in Crisopoli, 1794.

- According to Chardon de la Rochette (1812:70) Salvini's was not printed in London but in Florence, while O'Sullivan (2005:xix) suggests that it was printed simultaneously in Florence and London with a slightly different title. See Chardon de la Rochette, S. (1812). Mélanges de critique et de philologie, Volume 2. Paris: D'Hautel. Salvini lived for a while in London and the title page mentions Londra.

- Ibid., Di Senofonte Efesio degli Amori di Abrocome e d'Anzia libri cinque tradotti dal Greco da Antonmaria Salvini edizione seconda Corretta, ed Accresciuta, Londra [i.e. Florence?], 1757*.

- Reissued in Paris, 1781*; Venice: 1793.

- In Londra, 1792* reissued together with Gozzi's translation of Longus.

Signor Cavagliere Boccardi, Di Senofonte Efesio, degli Amori di Abrocome e d'Anthia libri V. Tradotti dal Signor Cavagliere Boccardi e dedicati a sua eccellenza il signor Marchese Neri Capponi, Cologne, 1730*.

\section{Chariton, Callirhoe}

\section{BILINGUAL EDITIONS (GREEK \& LATIN)}

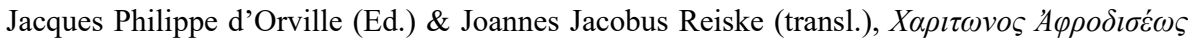

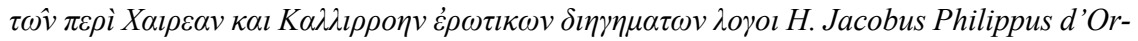
ville publicavit, animadversionesque adjecit. (Joannes Jacobus Reiskius vertit.), Amsterdam, 1750*.

— Reissued in Leipzig, 1783*.

\section{ENGLISH TRANSLATIONS}

Anonymous, The Loves of Chcereas and Callirrhoe. Written originally in Greek by Chariton of Afrodisios. Now first translated into English, London, 1764*.

FRENCH TRANSLATIONS

Pierre-Henri Larcher, Histoire des amours de Chereas et de Callirrhoë, Traduite du Grec, avec des Remarques, Paris: 1763*.

\footnotetext{
${ }^{74}$ See for the editions the ICCU.
} 
- In $1786^{75}$ in the Bibliothèque universelle des dames. Romans. Tom. 6, 7.

- Reissued as Les amours de Chereas et Callirrhoë, Traduites du Grec de Chariton, avec des remarques, par Pierre-Henri Larcher in 1797* in the Bibliothèque des romans grecs, traduits en français, Tome VIII.

Nicolas Fallet, Les Aventures de Chorée et de Callirrhoé, traduites du grec par M. Fallet, Amsterdam, 1775*.

\section{GERMAN TRANSLATIONS}

Anonymous, Charitons Liebesgeschichte des Chäreas und der Callirrhoe, Aus dem Griechischen übersetzt, Leipzig, 1753*.

\section{ITALIAN TRANSLATIONS}

Michelangelo Giacomelli, Di Caritone Afrodisieo de' Racconti amorosi di Cherea e di Callirroe libri otto, tradotti dal Greco, Rome, 1752*. — Reissued in Venice, $1755 ;^{76}$ s.1., $1756^{*}$.

- Ibid., Di Caritone Afrodisieo de’ Racconti amorosi di Cherea e di Callirroe libri otto, tradotti dal Greco da Monsignor Giacomelli, prelato della corte Romana, Paris, 1781*.

\section{Bibliography of consulted online catalogues}

Bayerische Staatsbibliothek (BSB). Available at: https://www.bsb-muenchen.de/

Biblioteca Nacional de España. Available at: http://catalogo.bne.es/uhtbin/webcat

Biblioteca Nazionale Centrale di Firenze. Available at: http://www.bncf.firenze.sbn.it/

Biblioteca Nazionale Centrale di Roma. Available at: http://bve.opac.almavivaitalia.it/ricerca Base.php

Biblioteca Nazionale di Napoli. Available at: http://polosbn.bnnonline.it/SebinaOpac/.do?sysb $=\mathrm{NAPBN}$

Biblioteca Nazionale Marciana. Available at: https://marciana.venezia.sbn.it/la-biblioteca/ cataloghi

Biblioteca Virtual Miguel de Cervantes. Available at: http://www.cervantesvirtual.com/

Biblioteka Narodowa. Available at: http://bn.org.pl/

Bibliothèque Mazarine. Available at: https://www.bibliotheque-mazarine.fr/fr/

Bibliothèque Municipale de Lyon. Available at: https://catalogue.bm-lyon.fr/

Bibliothèque National de France (BNF). Available at: http://catalogue.bnf.fr/index.do

Catalogue Collectif de France (Ccfr). Available at: http://ccfr.bnf.fr/portailccfr/jsp/public/ index.jsp

Deutsche Nationalbibliothek. Available at: http://www.dnb.de/DE/Kataloge/kataloge node. $\underline{\mathrm{html}}$

Det Kongelige Bibliotek. Available at: http://www.kb.dk/da/index.html

Gallica. Available at: http://gallica.bnf.fr/services/engine/search/advancedSearch/

\footnotetext{
${ }^{75}$ See information on the BNF: http://catalogue.bnf.fr/ark:/12148/cb41007986b [Accessed 21 March 2018].

${ }^{76}$ See the ICCU.
} 
Hungaricana project (Hungarian Cultural Heritage Portal). Available at: https://hungaricana.hu/en/

Ilmenauer Discovery Tool. Available at: https://find.bibliothek.tu-ilmenau.de/

Istituto Centrale per il Catalogo Unico delle biblioteche italiane e per le informazioni bibliografiche (ICCU). Availabe at: http://www.iccu.sbn.it/opencms/opencms/it//

Koninklijke Bibliotheek. Nationale Bibliotheek van Nederland. Available at: https://www.kb.nl/

Koninklijke Bibliotheek van België. Available at: https://www.kbr.be

Österreichische Nationalbibliothek (ÖNB). Available at: https://www.onb.ac.at/

Slovenská Národná Knižnica. Available at: http://www.snk.sk/en/

The British Library (BL). Available at: http://explore.bl.uk/primo_library/libweb/action/search. do?vid=BLVU1

Universal Short Title Catalogue (USTC). Available at http://ustc.ac.uk/index.php

\section{Bibliography of secondary literature}

Anonymous (C. d'I***) (1864). Bibliographie des ouvrages relatifs à l'amour, aux femmes, au marriage ... Par M. le C. $d^{\prime} I^{* * *} .2^{\text {nd }}$ ed. Paris: Chez Jules Gay.

Asor Rosa, A. (1999). Gambara, Lorenzo. Dizionario Biografico degli Italiani, 52, pp. 53-54.

Barber, G. (1989). Daphnis and Chloe: the markets and metamorphoses of an unknown bestseller.

London: British library.

Berger, G. (1988). Longo volgarizzato: Annibale Caro und Casparo Gozzi als Übersetzer eines problematischen Klassikers. In: H. Hofmann, ed., Groningen colloquia on the novel, vol. I. Groningen: E. Forsten, pp. 141-152.

Beta, S. (2015). Italus Achilles. Les premières traductions en langue latine et italienne du roman d'Achille Tatius publiées en Italie avant l'editio princeps du texte grec. In: B. Pouderon, ed., Les romans grecs et latins et leurs réécritures modernes: études sur la réception de l'ancien roman du Moyen Age à la fin du XIXe siècle. Actes du colloque de Tours octobre 2013. Paris: Beauchesne Editions, pp. 139-150.

Bianchi, N. (2011). Romanzi greci ritrovati: tradizione e riscoperta dalla tarda antichità al Cinquecento. Bari: Stilo.

Black, S. (2011). Reading mistakes in Heliodorus. Eighteenth-Century Fiction, 52(3-4), pp. 343-360.

Calvet-Sébasti, M.-A. (2015). La traduction française des romans grecs. In: C.B. Pouderon and B. Pouderon, eds., La réception de l'ancien roman de la fin du Moyen Âge au début de l'époque classique. Actes du colloque de Tours, 20-22 octobre 2011. Lyon: Maison de l'Orient et de la Méditerranée Jean Pouilloux, pp. 47-60.

Classe, O. (Ed.) (2000). Encyclopedia of Literary Translation into English. London, Chicago: Fitzroy Dearborn Publishers.

Clo, M. (2015). Amyot, Traducteur de Daphnis et Chloé. In: C.B. Pouderon and B. Pouderon, eds., La réception de l'ancien roman de la fin du Moyen Âge au début de l'époque classique. Actes du colloque de Tours, 20-22 octobre 2011. Lyon : Maison de l'Orient et de la Méditerranée Jean Pouilloux, pp. 87-98.

Colonna, A. (2015). Le etiopiche di Eliodoro. Torino: UTET.

Cozad, M. (2013). Textual Translation/Textual Transformation of a Greek Pastoral Romance: The First Appearance of Longus's "Daphnis and Chloe" in Golden-Age Spain. International Journal of the Classical Tradition, 20(4), pp. 127-135. 
de Armas Wilson, D. (2014). Allegories of Love: Cervantes's "Persiles and Sigismunda". 2nd ed. New Jersey: Princeton University Press.

Degen, J.F. (1798). Literatur der deutschen Uebersetzungen der Griechen. Altenburg: Richterschen Buchhandlung.

Doody, M. A. (1996). The true story of the novel. New Brunswick (N.J.): Rutgers University Press.

Ferrini, M.F. (1991). Bibliografia di Longo: Dafni e Cloe: edizioni e traduzioni. Macerata: Università degli studi di Macerata.

France, P., and Haynes, K. (2006). The Oxford history of literary translation in English. 4: 1790-1900. Oxford: Oxford University Press.

Gesner, C. (1970). Shakespeare and the Greek Romance: a Study of Origins. Lexington: University Press of Kentucky.

Gillespie, S., and Hopkins, D. (2005). The Oxford history of literary translation in English. 3: 1660-1790. Oxford: Oxford University Press.

Gual, C.G. (2011). The Ancient Novel and the Spanish Novel of the Golden Age. In: M. Futre Pinheiro and S. Harrison, eds., Fictional traces: receptions of the ancient novel. Eelde: Barkhuis, pp. 183-202.

Hofmann, H. (2011). The Expositi of Lorenzo Gambara di Brescia: a sixteenth-century adaptation in Latin hexameters of Longus's Daphnis and Chloe. In: M. Futre Pinheiro and S. Harrison, eds., Fictional traces: receptions of the ancient novel. Eelde: Barkhuis, pp. 107126.

Hoffmann, S.F.W. (1839). Bibliographisches Lexicon der gesammten Literatur der Griechen. Leipzig: A. F. Böhme.

Jankovics, J. (2005). Czobor Mihály és Gyöngyösi István Charicliája. [online] Kalligram. Available at: http://www.kalligramoz.eu/Kalligram/Archivum/2005/XIV.-evf.-2005.november-december/ELEINK/Czobor-Mihaly-es-Gyoengyoesi-Istvan-Charicliaja [Accessed 10 April 2018]

Kiss, F.G. (2017). Classical reception in Hungary: an Introduction. In: Zara Martirosova Torlone, Dana LaCourse Munteanu, Dorota Dutsch, eds., A Handbook to Classical Reception in Eastern and Central Europe. Chichester: John Willey \& Sons, pp. 225-232.

Krzyźanowski, J. (1984). Literatura polska: przewodnik encyklopedyczny, Volume 2. Warschau: Państwowe Wydawnictwo Naukowe.

Krzyźanowski, J. (2012). Etiopiki, Historie etiopiskie. [online] Eduteka. Available at: http://www.eduteka.pl/doc/etiopiki-historie-etiopskie [Accessed 14 February 2018].

Létoublon, F. (2015). Jacques Amyot, inventeur du roman grec. In: C.B. Pouderon and B. Pouderon, eds., La réception de l'ancien roman de la fin du Moyen Âge au début de l'époque classique. Actes du colloque de Tours, 20-22 octobre 2011. Lyon: Maison de 1'Orient et de la Méditerranée Jean Pouilloux, pp. 61-86.

MacQueen, B.D. (1990). Myth, Rhetoric, and Fiction: a reading of Longus's Daphnis and Chloe. Lincoln, London: University of Nebraska Press.

Möckel, S. (2007). Zwischen Muster und Anverwandlung. Übersetzungen des antiken Liebesromans in der Frühen Neuzeit. In: H. Böhme, C. Rapp, and W. Rösler, eds., Übersetzung und Transformation. Berlin, New York: De Gruyter, pp. 137-155.

Nakatani, S. (2005). Achilles Tatius and beyond: studies in the History of Reception of Leucippe and Clitophon in Modem Europe. PhD diss. Swansea. Swansea University, UK.

Oeftering, M. (1901). Heliodor und seine Bedeutung für die Literatur. Berlin: Verlag von Emil Felber. 
Pettegree, A., Walsby, M., and Wilkinson, A. (2007). French Vernacular books: books published in the French language before 1601. Leiden: Brill.

Plazenet, L. (1997). L'ébahissement et la délectation: réception comparée et poétiques du roman grec en France et en Angleterre aux XVIe et XVIIe siècles. Paris: H. Champion.

Plazenet, L. (2002). Jacques Amyot and the Greek Novel: the Invention of the French Novel. In: G. Sandy, ed., The Classical Heritage in France. Leiden, Boston, Köln: Brill, pp. 237280.

Plepelits, K. (1996). Achilles Tatius. In: G. Schmeling, ed., The Novel in the Ancient World. Leyden: BRILL, pp. 387-416.

Rajka, L. (1917). Heliodoros Aithiopikájának Feldolgozásai A Magyar Irodalomban. Koloszvár: Magyar Irodalomtörténeti Szeminárium. Available at: http://mek.oszk.hu/16300/ 16310/16310.pdf [Accessed 22 March 2018]

Rattenbury, R.M. (1925). The Manuscripts and Editions of Heliodorvs. The Classical Quarterly, 19(3/4), pp. 177-181.

Rattenbury, R.M. (Ed.), Lumb, T.W. (Rev.), and Maillon, J. (transl.) (1960). Héliodore: Les Éthiopiques: (Théagène et Chariclée). 2e édition. Paris: Belles Lettres.

Reeve, M. (2008). The re-emergence of ancient novels in western Europe, 1300-1810. In: T. Whitmarsh, ed., The Cambridge companion to the Greek and Roman novel. Cambridge: Cambridge University Press, pp. 282-298.

Rose, C.H. (1971). Alonso Núñez de Reinoso: the lament of a sixteenth-century exile. Cranbury [N.J.]: Fairleigh Dickinson University Press.

Sandy, G.N. (1979). Ancient Prose Fiction and Minor English Novels. In: Antike und Abendland, Band xxv Heft 1. Berlin, New York: De Gruyter, pp. 41-55.

Sandy, G.N. (1982). Heliodorus. Boston: Twayne.

Sandy, G.N., and Harrison, S. (2008). Novels ancient and modern. In: T. Whitmarsh, ed., The Cambridge companion to the Greek and Roman novel. Cambridge: Cambridge University Press, pp. 299-320.

Seeber, S. (2017). Heliodor unter der Tarnkappe: Zschorns Übersetzung der Aithiopika (1559) im Kontext der Zeit. In: R. Toepfer, J.K. Kipf, and J. Robert, eds., Humanistische Antikenübersetzung und frühneuzeitliche Poetik in Deutschland (1450-1620). Berlin/Boston: De Gruyter, pp. 511-526.

Urbanowicz, A. (2002). Heliodor: OPOWIEŚĆ ETIOPSKA O THEAGENESIE I CHARIKLEI. Z języka greckiego przełożył, wstępem i przypisami opatrzył Sylwester Dworacki. Poznań 2000 ss. 371. Wydawnictwo Naukowe Uniwersytetu im Adama Mickiewicza. Posnańskie Studia Teologicsne, 13, pp. 300-301.

Vieillefond, J.-R. (Ed.) (1987). Longus: Pastorales: Daphnis et Chloé. Paris: Les Belles Lettres.

Vieillefond, J.-R. (2016). Longus, Annibal Caro et Paul-Louis Courier. Prometheus. Rivista di studi classici, pp. 274-282.

Xenophon Ephesius, \& O'Sullivan, J.N. (Ed.) (2005). De Anthia et Habrocome ephesiacorum libri $V$. Monachii: Saur. 